\title{
Kárpátalja turisztikai vonzerőinek nyelvi tájképe
}

\author{
KARMACSI ZOLTÁN ${ }^{1}$
}

\begin{abstract}
ABSZTRAKT
A nyelvi tájkép változása különösen érzékenyen érinti a kisebbségi helyzetben lévő lakosokat, akik ennek köszönhetően akár ki is szorulhatnak a virtuális nyelvhasználati térből. A nyelvi tájkép nemcsak egy terület vagy régió lakosságának nyelvi vitalitását jelzi, hanem akár a valóságbeli nyelvi etnicitást is tükrözheti. A nyelvi kiírások két alapfunkciója és a nyelvi tájkép elemeit magyarázó modellek mellett azonban a nyelven kívüli tényezők sem hanyagolhatók el. Ilyen tényező egy-egy térség, kisebb régió gazdasági, esetünkben turisztikai fejlődése. A megnövekedett többségi lakosok turisztikai kereslete számos olyan jelenséget hív elö a kisebbség által lakott területen, amelyek mindenképpen jelentös hatást gyakorolnak a kisebbségi terület nyelvi tájképére.

Jelen tanulmányomban arra szeretnék rávilágítani, hogy az adott terület nyelvi tájképének alakulására milyen hatást fejt(het) ki egy kistérségi gazdasági beruházás. A nyelvi tájképben bekövetkezett változást a Hodinka Antal Nyelvészeti Kutatóközpont 2011-2012. évi fényképes adatbázisa és a 2016 februárja és szeptembere, illetve 2017 hasonló időszakának saját magam általi megfigyelése és fényképes rögzítése alapján szeretném bemutatni.
\end{abstract}

KULCSSZAVAK: nyelvi tájkép, turizmus, nyelvi tájkép változás, gazdasági hatások, Kárpátalja, magyar kisebbség

\section{ABSTRACT}

\section{Linguistic Landscape of Turistical Attractions in Transcarpathia}

The change of the linguistic landscape is a sore spot for the minority population that can be driven out of the virtual language use. Linguistic landscape is not only indicative of the language vitality of an area or region's population, but can also reflect the real language ethnicity. Extralinguistic factors are as important as the two basic functions of linguistic texts and the models explaining the elements of the linguistic landscape. Such a factor is a small area or region's economic, in our case touristic development. The increased tourist demand of the majority brings about numerous phenomena that are of significant influence on the linguistic landscape of the minorities' territory. This research is aimed at revealing the influence a local economic investment makes (can make) on the formation of the territory's linguistic landscape. I would like to show the changes in the linguistic landscape recorded by Hodinka Antal Research

${ }^{1}$ II. Rákóczi Ferenc Kárpátaljai Magyar Főiskola, Beregszász, docens. 


\section{TEMATIKUS TANULMÁNYOK - Kárpátalja társadalma}

Centre in its photo database of 2011-2012, February and September of 2016, as well as of 2017 on the basis of my observations and photographs.

KEYWORDS: linguistic landscape, tourism, change of the linguistic landscape, economic influence, Transcarpathia, Hungarian minority.

\section{Bevezetés}

A kárpátaljai magyarság gazdasági életképességét tekintve Kárpátalja iparilag fejletlen vidék és mezőgazdasági területekben sem bővelkedik, amelynek egyik egyenes következménye a kevés munkalehetőség és munkahely. A területen élők egyik kitörési pontja a turizmus (Berghauer 2012, Rada 2015), mely szempontjából Kárpátalja az ideérkező turistákat főként Ukrajna más megyéiből és a szomszédos országokból várja (Sass 2012). Ezen adatok mentén Kárpátalja, s fóként a magyarok által lakott területek nyelvi tájképében érdemes megvizsgálni, hogy a turizmus milyen szerepet tölt be, funkcionálisan hogyan játszik közre a nyelvek megjelenési arányának alakulásában. A tanulmány Kárpátalja épített és természetes turisztikai vonzerőinek nyelvi tájképére és a vonzerők nyelvi tájképre gyakorolt hatását kívánja feltárni.

\section{A turizmus helyzete Kárpátalján}

Ukrajna területileg erősen koncentrált turizmusában Kárpátalja az öt turisztikai központ közül a negyedik helyre rangsorolt Kárpátok vidéke nyugati turisztikai centrumban foglal helyet (Sass 2008, Berghauer 2012). A megye fő turisztikai irányvonalai és vonzerői a gyógyturizmusban, hegyvidéki turizmusban, illetve a kulturális és örökségturizmusban rejlenek. Kiemelkedő a termálvizek látogatottsága, hiszen Ukrajna területén csak a Kárpátaljai artézi medencében és a Fekete-tenger-melléki artézi medencében található termálvíz (Ukrajna Nemzeti Atlasza 2009: 145). Ezek hasznosítása főként Kárpátalja területén jellemző, de a Fekete-tenger-melléki artézi medencében (Herszon megye és Krím) is vannak hasznosított források (URL3, URL4). Kárpátalján külön tematikus turistautat is létrehoztak Kárpátalja geotermikus vize néven, amelyben 7 kárpátaljai termálfürdő kapott helyet (vö. Tematikus turistautak Kárpátalján).

A Krími Autonóm Köztársaság Oroszország általi 2014-es annektálását követen a belföldi turizmus irányt vált, hiszen Ukrajna öt idegenforgalmi központjának legkiemelkedőbb tagját veszítette el (Sass 2008, 2016). Ennek köszönhetően a belföldi turizmus nagyobb arányban jelenik meg Kárpátalja területén, amely így mintegy kompenzálja a 2014-es események miatt elmaradó külföldi, főleg magyarországi vendégek hiányát (Sass 2016), akik főként a „háborús” helyzet miatt maradnak távol. Azonban ezen irányváltást hiába is keressük a statisztikai adatokban, mivel az 


\section{TEMATIKUS TANULMÁNYOK - Kárpátalja társadalma}

nem tükrözi a valóságot. Kárpátalja Statisztikai Évkönyvében $(2017)^{2}$ a kiszolgált turisták ${ }^{3}$ száma 2000-ben volt a legmagasabb, s azóta kisebb megingásokkal folyamatos csökkenést mutat: 2012-ben 20180 fö, 2013-ban 19892 fö, 2014-ben 11625 fó, 2015-ben 10656 fó és 2016-ban 11601 fó. Ezek közül a legnagyobb hányadát (átlagosan a 2/3-át) a külföldre utazó ukrán állampolgárságú turisták teszik ki. A valóságtól még jelentősebben elrugaszkodik a statisztikai adatbázis a külföldi turistaforgalom esetében, mely szerint a Kárpátaljára érkező turisták éves száma 2012-ben 733 fő, 2013-ban 515 fö, 2014-ben 6 fo,, 2015-ben 13 fó és 2016-ban 68 fő (Kárpátaljai Statisztikai Évkönyv 2016, 2017: 186). A Kárpátalja megyei gazdaságfejlesztési és kereskedelmi főosztály tájékoztatása szerint viszont Kárpátalján több mint egymillió, főleg belföldi turista fordult meg idén (sic! 2017-es év első 8 hónapja alatt), míg a külföldiek közül elsősorban a cseheket, lengyeleket és románokat vonzotta az ukrajnai régió (URL2). Hennagyij Moszkal, a Kárpátaljai Megyei Állami Közigazgatási Hivatal elnöke rekordszámú, közel kétmillió Kárpátaljára látogató turistáról nyilatkozik a 2017-es év tekintetében (URL5). Ha a megyei gazdaságfejlesztési és kereskedelmi főosztály, illetve az állami közigazgatási hivatal elnöke által közölt adatokat összevetjük az elmúlt három év statisztikai adataival, akkor megállapíthatjuk, hogy az idei évben közel 180-szor annyi turista érkezett a megyébe, mint tavaly. Természetesen ez nem így van, hiszen csak a Munkácsi várat 2015-ben 124290-en, míg 2016-ban 277 722-en látogatták (URL1), s 2017-ben pedig 282460-an (URL8). Vagyis elképzelhetetlen, hogy a statisztikai kimutatás szerint Kárpátaljára 2015-ben 3062 és 2016-ban 3664 külföldi és belföldi turista érkezett, s mindeközben a 2015ben ennek közel 40-szerese, 2016-ban pedig közel 70-szerese kereste fel a Munkácsi várat. Vagy netalán minden Kárpátaljára érkező turista megközelítőleg 5-ször járt Munkács várában ittléte alatt?!

\section{Nyelvi tájkép és kisebbségi helyzet}

A mai Kárpátalja területét számos államalakulat birtokolta több-kevesebb ideig. Az ezeréves magyar fennhatóságot a trianoni békedöntés után a csehszlovák éra, a Podkarpatszka Rusz követte egészen 1938/1939-ig, amikor is a terület újra magyar fennhatóság alá került. 1944-től a volt Szovjetunió része lett, majd széthullása után napjainkban a független Ukrajna legnyugatibb megyéje (Baranyi 2009, Csernicskó 2013: 18). E politikai sokszínűség erőteljesen rányomta az itt élők anyanyelvére, nyelvhasználatára is a bélyegét, hiszen a hatalomváltással sok esetben államnyelv-

\footnotetext{
${ }^{2}$ Kárpátalja 2017 nyarán kiadott statisztikai évkönyvében a 2016. évi adatok kerülnek feldolgozásra.

${ }^{3}$ Kiszolgált turisták fogalma alatt értik az Ukrajnába érkező külföldi turistákat, az Ukrajnából külföldre látogató ukrán állampolgárságú turistákat és a belföldi turistákat.
} 


\section{TEMATIKUS TANULMÁNYOK - Kárpátalja társadalma}

váltás, új nyelvpolitikai elképzelések érvényesültek. ${ }^{4}$ E törekvéseknek köszönhetően Kárpátalja területén az államnyelvekhez igazodva a helynevek, a hivatalok és közintézmények nevei, hivatali ügyintézés tájékoztatói, a lakossági hirdetések stb. szintén több kisebb-nagyobb változást éltek meg, melynek következtében a nyelvi tájkép, és azon belül a nyelvek arányának megoszlása is változott. A nyelvi tájkép változása különösen érzékenyen érinti a kisebbségi helyzetben lévő lakosokat, akik ennek köszönhetően akár ki is szorulhatnak a virtuális nyelvhasználati térből. Landry és Bourhis (1997: 25) szerint egy adott terület, régió és városi agglomeráció nyelvi tájképe ${ }^{5}$ jelzésértékű az adott területen lakó nyelvi közösségek nyelvi vitalitását illetően. Hires-László (2015: 160) szerint a nyelvi tájkép még ennél is tovább mutat, hiszen a valóságban megélt etnicitás részévé válhat, amikor az egyének a köztereken járva, a mindennapi életüket élve nyelvi elemekkel találkozva szembesülnek az etnikumuk nyelvi szerepével és ezzel együtt az adott terület nyelvi hierarchiáival. A feliratoknak két alapfunkciója (kommunikatív és szimbolikus) egy kissebségi helyzetben lévő népcsoport számára fontos szereppel bírhat, ahol az etnikum válik láthatóvá a közterek kiírásaiban, vagy bármely más írott nyelvi színtéren (Landry-Bourhis 1997, idézi Laihonen 2012: 27). De egy új államnyelvhez (jelen esetben az ukránhoz) kapcsolt nyelvi jogi rendszer megvalósulását is érthetjük a két alapfunkción, ahol az államnyelv megjelenésének szerepeit láthatjuk külön a formális és informális színterek kiírásaiban (Hires-László 2015: 161). Az egyes nyelvi tájképek elemeit az alábbi négy tényező magyarázhatja: 1 . hatalmi viszonyok, 2. kommunikatív célok, 3. önkifejezés, 4. kollektív identitás kifejezése. A feliratok megrendelőinek szándéka, illetve a táblákat olvasók értelmezésének tekintetében e tényezők közül egyszerre több is érvényes lehet (Ben-Rafael - Shohamy - Barni 2010, Laihonen 2012).

\section{Megjelenés a térben: reklámanyagok, kiadványok, prospektusok és tájékoztatók}

A turisztikai kereslet felkeltése és informálása szempontjából alapvető fontosságú az egységes turisztikai brand kialakítása, fenntartása, s az ehhez kapcsolódó turisztikai anyagok elhelyezése mind a valóságos, mind pedig a virtuális térben.

A Kárpátalja Megyei Állami Adminisztráció Gazdaságfejlesztési és Kereskedelmi Főosztályának Turisztikai és Üdülési Hivatala 2016 tavaszán kezdi el Kárpátalja turisztikai brandjének kidolgozását ${ }^{6}$, amelynek létrehozását a Megyei Tanács még az

${ }^{4}$ E bonyolult problémakört a hely szűke miatt nem boncolgatom, de részletesen olvashatunk róla Csernicskó István: Államok, nyelvek, államnyelvek című monográfiájában, amely 2013-ban látott napvilágot.

${ }^{5}$ Landry és Bourhis ezalatt a hivatalos útjelző táblákat, a reklámtáblákat, utcaneveket, helyneveket, kereskedelmi egységek feliratait és kormányzati épületek hivatalos tábláit értik.

${ }^{6}$ Ez is része a Kárpátalja megyei turisztikai és üdülési fejlesztési programja a 2016-2020 közötti időszakra című fejlesztési projektnek. 


\section{TEMATIKUS TANULMÁNYOK - Kárpátalja társadalma}

év őszén megszavazza. Ennek keretében kerül elfogadásra a megye turisztikai logója is (URL6, 1. ábra).

\section{1. ábra. Kárpátalja ukrán és angol nyelvű turisztikai logója}

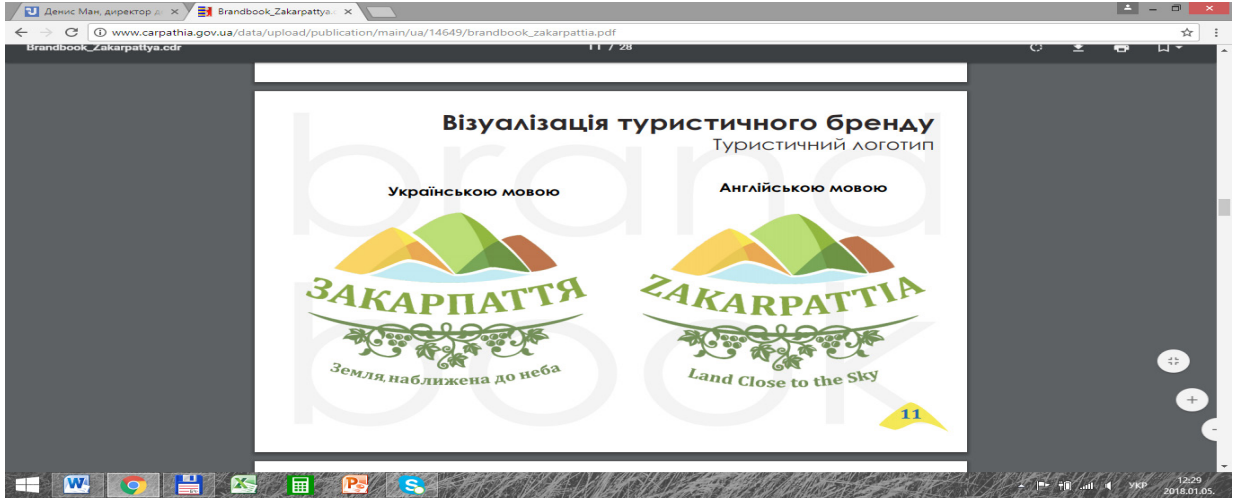

Forrás: URL6: 11

A turisztikai logót az állam hivatalos nyelvén, vagyis ukránul, illetve a nemzetközi érintkezésekben használt angol nyelven hagyta jóvá a grémium. Azonban Kárpátalja történelmi és etnikai viszonyait figyelembe véve, a turisztikai célközönség szempontjából mindenképpen ajánlatos lett volna a logó nyelvi palettáját bővíteni. Hacsak a terület korábban részletezett különböző államok álatali birtoklását vesszük alapul, akkor az Osztrák-Magyar Monarchiához való tartozás során számos német ajkú ember számára lehet érdekes e táj. Még sorosabb történelmi érdeklődés figyelhető meg Magyarország irányából, s ezt az 1990-es évektől mai napig beáramló magyar turizmus is alátámasztja. Ez alapján a logó magyar nyelvű elkészítése is indokolt lehetne, mivel az angol nyelvű transzliteráció (Zakarpattia) a magyar célközönségnek nem cseng olyan ismerősen, mint a Kárpátalja. De a csehszlovák éra tekintetében még cseh, szlovák, román és lengyel nyelvü logó is belefért volna, hiszen Kárpátalja Megyei Állami Adminisztráció Gazdaságfejlesztési és Kereskedelmi Főosztályának tájékoztatása szerint a külföldiek közül elsősorban a cseheket, lengyeleket és románokat vonzotta 2017-ben Kárpátalja.

Kárpátalja hivatalos turisztikai-információs honlapja (http://www.transcarpathiatour.com.ua) ukrán és orosz nyelven érhető el, s ugyan az angol nyelvű lehetőség is fel van tûntetve, de annak alkalmazása nem múködik. Ennek fényében elmondható, hogy a megye turizmusa iránt érdeklődők csak az ukrán és orosz nyelven kommunikálók érhetik el a virtuális információbázist, míg a latin betűs írásmódot használók a megye hivatalos információszolgáltatásához nyelvismeret hiányában nem férhetnek hozzá. 


\section{TEMATIKUS TANULMÁNYOK - Kárpátalja társadalma}

Kárpátaljai Megyei Állami Adminisztráció elnökének 426. számú megbízása alapján került kidolgozásra a Kárpátalja megyei turisztikai és üdülési fejlesztési programja a 2016-2020 közötti időszakra (továbbiakban Program). A Program többek között előirányozza az előző bekezdésben említett Kárpátalja hivatalos turisztikai-információs honlapjának Európai Uniós nyelvekre történő lefordítását. Továbbá előirányozza kétnyelvű turisztikai információs táblák kihelyezését, viszont nem tesz említés, hogy melyik két nyelven. Vagyis a megye turisztikai és üdülési program keretében a megye vezetése szorgalmazza az államnyelv hegemóniájának csökkentését, s ezzel elősegítse a külföldi turisták bevonzásának nagyobb lehetőségét is.

A Programnak köszönhető az is, hogy már 2016-ban - a korábbi években általában csak államnyelvi, vagy esetleg angol fordítással kiegészült kiadványok voltak a jellemzők - megjelent néhány reklámanyag, kiadvány, amelyre az államnyelven és az angolon kívül más nyelven is felkerültek az információk. Ilyen például a négy nyelven (ukrán, angol, magyar, szlovák) megjelentetett Kárpátalja középkori várai (2016) képeslapgyújtemény (2. ábra), vagy a Kárpátaljai bor (Fedir, Deák 2010, 2016a, 2016b, 3. ábra) három különálló ukrán, angol és magyar nyelvü programajánló brosúra.

2. ábra. A Huszti várromot ábrázoló, négynyelvű információt tartalmazó képeslap
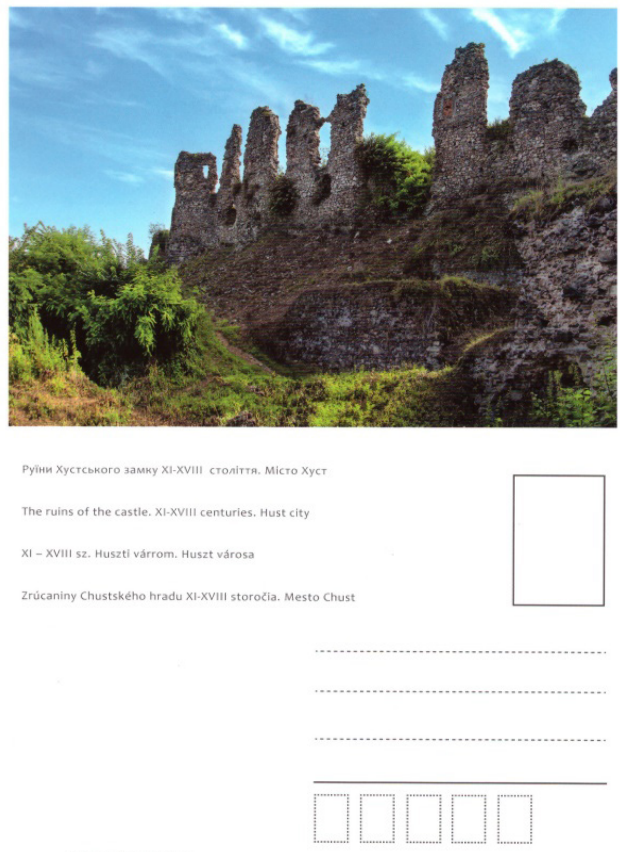

Forrás: Kárpátalja középkori várai képeslapgyűjtemény 2016 
www. metszetek.unideb.hu

\section{TEMATIKUS TANULMÁNYOK - Kárpátalja társadalma}

3. ábra. A Kárpátalja borait és borútját népszerűsítő ukrán, magyar és angol nyelvű kiadvány borítója
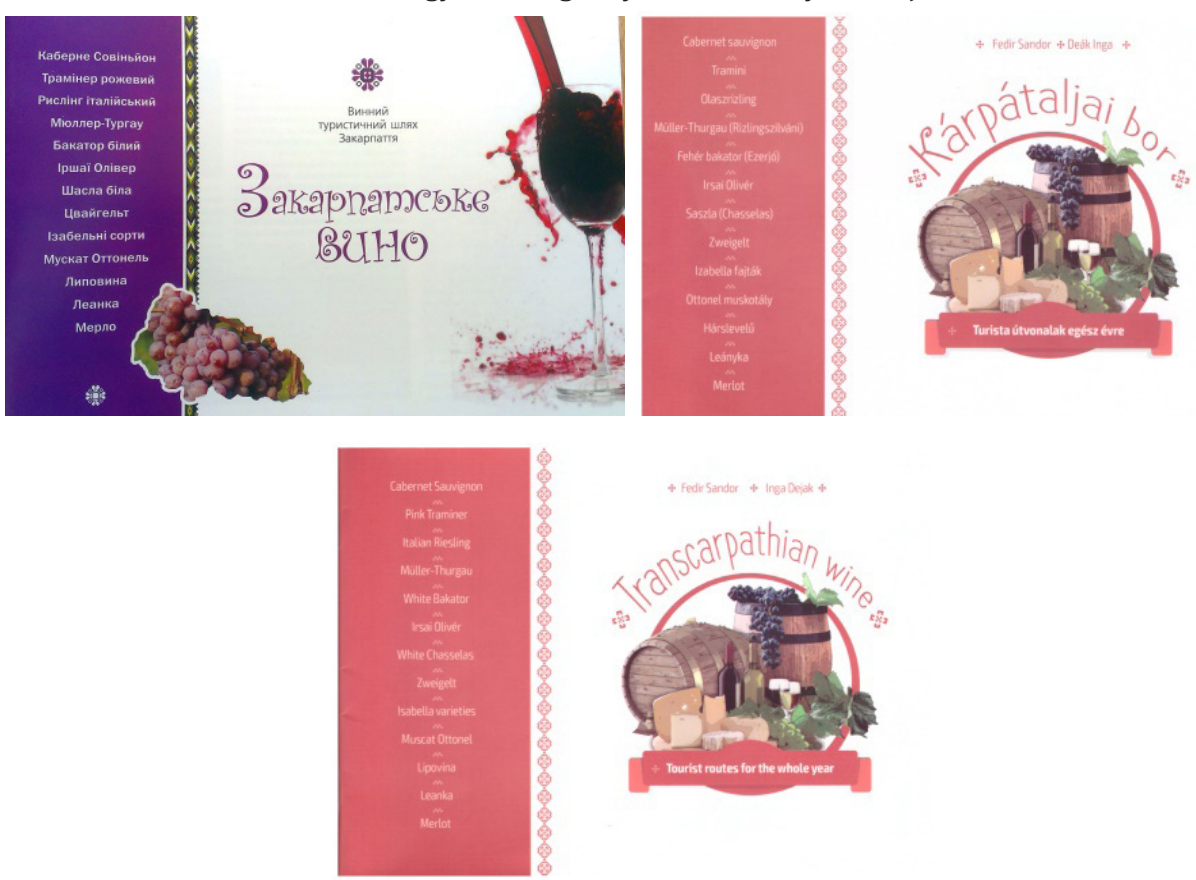

Forrás: Fedir - Deák 2010, 2016a, 2016b

Ennek ellenére a legtöbb turisztikai népszerűsítő kiadvány továbbra is az államnyelven jelenik meg Kárpátalja turisztikai nyelvi tájképében. Többek között a terület turisztikai eseményeit népszerűsíteni hivatott Kárpátalja turisztikai eseményeinek kalendáriuma 2017-es évre, amely nyomtatásban is megjelent, illetve a 2018-as pedig elérhető az megyei állami adminisztráció weboldalán (http://carpathia.gov. ua/data/upload/publication/main/ua/14678/26.pdf). Pedig a programkínálatok többnyelvű megjelentetése lehetne az egyik esélye a minél több külföldi turista Kárpátaljára való csalogatásának.

A megye kisebb területét felölelő turisztikai vonzáskörzetek, vállalatok, magánvállalkozások az üzleti lehetőségeiket bővítve igyekeznek nemcsak a hazai keresletre alapozni, s ennek érdekében a reklám- és információs tevékenységüket az ukránon kívül főként angol, esetleg más nyelvre is kiterjesztik (vö. 4. ábra). 


\section{TEMATIKUS TANULMÁNYOK - Kárpátalja társadalma}

4. ábra. A Borzsa-völgy keskenynyomtávú vasút prospektusa

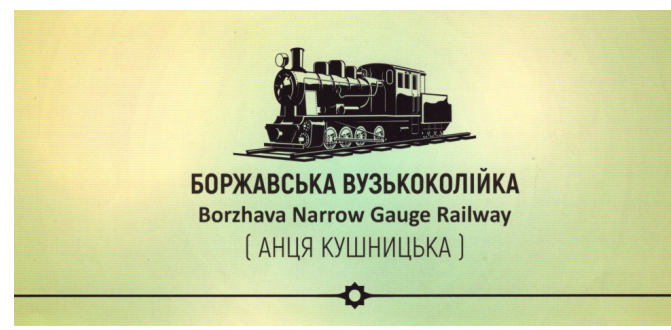

Forrás: Szóróanyag

Különös ilyen szempontból a Beregvidék, melynek turizmusa korábban főként a Magyarország felől érkező turizmusra alapozott. A Beregvidék a jelentősen megnövekedett és napjainkban is bővülő ukrán belföldi piacról érkező vendégeken kívül még mindig jelentős számú magyar turistával is számol. Ebből kifolyólag a reklámanyagok, tájékoztatók, információs anyagok többsége magyar-ukrán nyelvü, vagy esetenként csak magyar vagy csak ukrán nyelven jelenik meg. Például a hagyományosan minden évben megrendezésre kerülő BEREGFEST fesztivál programja is két nyelven kerül a szóróanyagra (5. ábra). A szervezők arra is figyeltek, hogy az ukrán nyelvű szöveg esetében a kijevi időt tüntették fel (GMT+2), addig a magyar nyelvű szövegrésznél közép-európai időt tüntettek fel $(\mathrm{GMT}+1)^{7}$. Ez azért is kézenfekvő megoldás, hiszen ez nemcsak a külföldi (főként magyar) turisták számára lesz érthető, hanem a helyi magyar közösség számára is, hiszen ők a mindennapjaikat is a közép-európai idő szerint élik.

Az állami büdzsé által finanszírozott idegen nyelv(ek)re lefordított kiadványokban előfordulnak nem megfelelő, olykor gépi vagy tükörfordítások, melyek szintén kedvezőtlenül hathatnak az idecsalogatni kívánt külföldi turistára. De ilyen fordítások vállalatok és egyéni vállalkozók hirdetéseiben vagy termékeinek leírásában is előfordulnak. Az egyik kárpátaljai magánvállalkozó csokoládéjának ${ }^{8}$ termékleírását négy nyelven tünteti fel a doboz hátoldalán (4. ábra), amely nyelvi és üzleti szempontból is előnyös. Azonban az ukrán nyelvből való fordítások itt is hagynak maguk után kívánni valót. A magyar fordításban az ukrán глазур szót jegesedésként fordítják, melynek eredeti jelentése máz, bevonat. Ugyancsak nem megfelelő a fordítása a цукерки пісні (ömlesztett csokoládé) kifejezésnek, amely böjtös csokoládé fordításként jelenik meg. De az ароматизатор «Ванилин» sem a magyar nyelv hangzásának megfelelően került fordításra, hiszen az aroma „vanillin” a magyar nyelvben vanília aroma-ként használatos (6. ábra). 
www. metszetek.unideb.hu

\section{TEMATIKUS TANULMÁNYOK - Kárpátalja társadalma}

\section{5. ábra. A BEREGFEST 2017 magyar-ukrán nyelvű prospektusa}

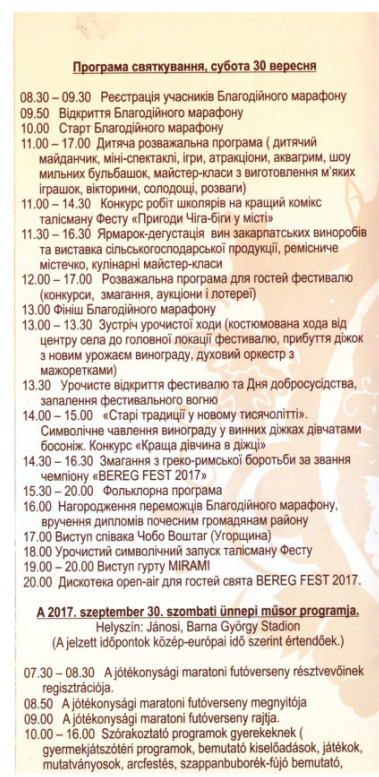

\section{BEREG FEST 2017}

\section{kézmüves rongybabakk k}

édességek, sorjatékok.)
$0.00-13.30$ Iskolások trélás sorozatrajz stilusú (comics) rajzversenye a rendezvenyy kabalafiguraja Csigabiga kalandja városban cimmel.
$0.30-15.30$ Kóstolással egybekótott boràszat kiallitas a kápátalajai boráazzok kinálatából, valamint mezỏgazdasági és
ipari termékek kiállíása, kézmüves készítmények bemutatása és vására.

$11.00-16.00$ További szzorakoztató programok (versenye vetêkkedōk, árverés, lombola, stb.)
$2.00 \mathrm{~A}$ jótékonysági maratoni futoverseny befutojja.

12.00 - 12.30 Népviseletbe öltiozzött mükedvelök ünnepélyes

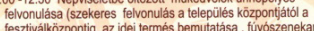
feszivákiközpontig, az idei termés bemulatása , fúvószenekar mazsorettekkel, stb.

30 A BEREGFEST és a Jószonszédsági Napok ünnepélyes megnyitója és a feszzivál lángiának meggyútása.
$30-16.30$ Vendéglátás magyar módra. A magyar konyha és világ bemutatója a vidék venóéglátóninak és mesterszakóćcsain

közremüködésévével.
$3.00-14.00$ Régi szokások és hagyományok az ujj evezredben A hagyomảnyos szōótaptaposás bemutatása lányok

szépségverseny.
30 . 15.30 Köttiogású birkózóverseny a BEREGFEST 2017

bainoka cím elnyeréséért
4.30 - 19.00 Hagyományôrzo egyưttesek, énekesek és táncoscoportok bemutatá elöadás

A jótékonysági maratoni futbouverseny dijátadó ünnepsége. A Jaras tiszteietbeli polgâarainak szolo oklevelek

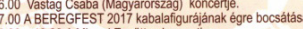
$00-19.00$ A Mirami Egyites konoejte

1900 A BEREG FEST 2017. szabadtéri diszkóprogramia

\section{Програма святкүвання, неділя 1 жовтня}

10.00 Старт веломарафону жУкраїна без віз - дружба без 10.00 - 12.00 Турнір 3 міні-футбогу серед дитячих команд н זYбOK «BEREG FEST OPEN 2017”

$.00-17.00$ Дитяча розвакальна програма (дитячий майданчик, міні-спектаклі, ігри, атракціони, аквагрии, шоу іграшок, вікторини, солодощі 200 Божественна пітургія в храмі с.Яноші до свята Покрови
Пресвятої Богородиці

2.00 - 16.00 Ярмарок-дегустація вин закаргагських виноробів та виставка слльськогосподарськоі продуки б, ремісниче містечко, кулінарні майстер-класи

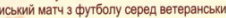
команд
$13.00-17.00$ Турнір з петанку на кубок «BEREG FEST 2017” 15.00 - 17.00 Фінал кубку Берегівсьюого району з футболу 16.00 Урочистий запуск талісману фестивалю
17.30 - 18.30 Виступ фіналістки програми «Голос країни. Діти Іванни Решко

рна програм

A 2017. október 1. vasárnapi ünnepi müsor programja. Helyszin: Jánosi, Barna György Stadion

99.00 A Vizummentes Ukrajna - Barátság határok nélkü enevezésú kerékparverseny rajta

9.00 - 11.00 Kispályás fociverseny az ifususági korosztäly számára a ,BEREG FEST OPEN 2017' kupa elnyeréséés
$0.00-16.00$ Szórakoztató gyermekprogramok.

gyermekiátszótéri programok, bemutató kiseláadások, átékok mutatványosok, arćestés, szappanbuborék-fújób bemutató, kézmüves rongybabák készitése, vetếlkedök stb. 11.00 Szent liturgia a makkosjánosi Mária Oltalma görōg katolikus

1.00 - 15.00 Mezôgazdasági és ipari termékek kiâllitása és vására (kézmüves sarok, mesterek és készitmények bemutatása.)

1.00 A kerékppárverseny diáátadó ünepsége. A Csigabiga

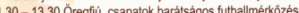
12.00 - 16.00 Pétanque (golyósport) verseny a BEREG FEST 2017

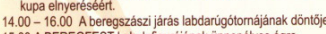
15.00 A BEREGFEST kabalafiguráának ünnepélyes égre bocsalása

6.30 - 17.30 Resko Ivanna, az Orszég gyermekhangja verseny résztveröéének konncertie.

.30 - 19.00 - Néphagyományokat ápolb együttesek, ènekesek é 19.00 Szabadtéri diszkó

\section{Forrás: Szóróanyag}

6. ábra. Egy kárpátaljai magánvállalkozó csokoládéjának négy nyelven írott tájékoztatója (balra), illetve ukrán és magyar nyelvű kiemelt tájékoztatója (jobbra)

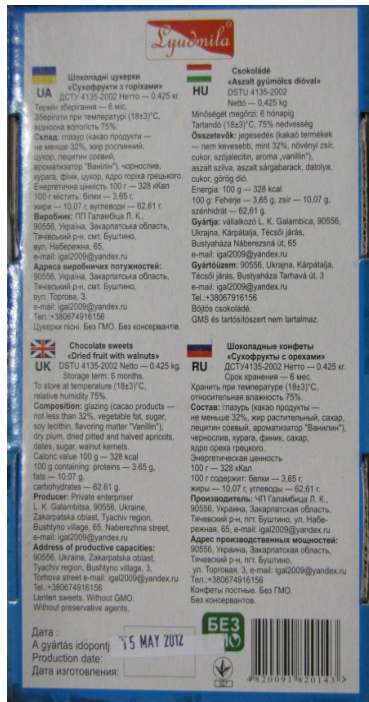

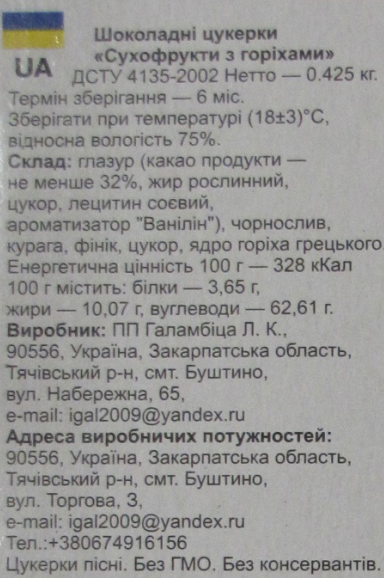

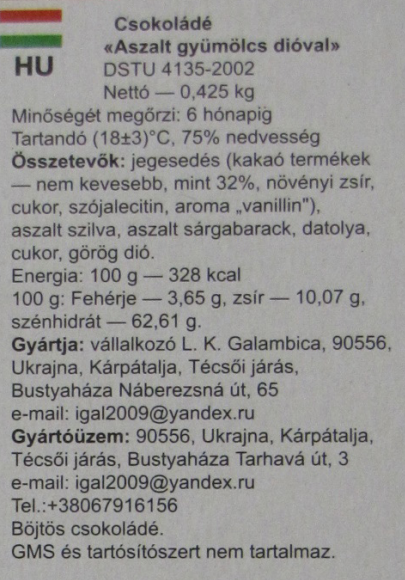

Forrás: Kereskedelmi termék 


\section{TEMATIKUS TANULMÁNYOK - Kárpátalja társadalma}

\section{Turisztikai látványosságok és vonzerők nyelvi tájképe}

Kárpátalja turisztikai látnivalóinak és vonzerőinek nyelvi tájképét erősen uralja az államnyelv, az ukrán. Azonban a 2012-es évtől, amikor is Ukrajna Lengyelországgal közösen rendezte a futball Európa bajnokságot, az államnyelvi turisztikai információk mellett idegen nyelvű fordításaik is megjelentek. Persze ez nem volt jellemző a teljes megye területére, hanem főként a fő közlekedési folyosók (főutak) mentén és a nagyobb városok (pl. Ungvár, Munkács) közterein, ahol nagyobb létszámú külföldi turista felbukkanására lehetett számítani. Természetesen a várt turistaáradat elmaradt, de az információs táblák maradtak a helyükön.

A legtöbb „kétnyelvűsített” tábla a fơútvonalak mentén lévő települések névtáblái, határátkelőket jelölő és egyéb információs táblák voltak. A fordítók előszeretettel nyúltak a transzliteráció megoldáshoz, mely nem segítette és nem segíti napjainkban sem a könnyebb nyelvi megértést a szláv és cirill írásmódú kultúrkörben kevésbé jártas külföldi turisták számára. Több magyarlakta település határában a már két nyelven kihelyezett névtáblák magyar változatának helyére kerültek ezek az angol nyelvű transzliterációs változatok az ukrán nyelvű név mellé. Csernicskó István e kötetben olvasható tanulmányában a tranliteráció alkalmazását a Beregszász központjában lévő kétnyelvű útjelző táblának példáján mutatja be. E táblán a cirill betűs ukrán és latin betűs angol nyelvű feliratok esetében „Лужанка/Luzhanka”, a „Вілок/Vilok” és а „Дяково/Dyakovo” határátkelőhelyek neveinek átirata nemcsak a településnév és a nemzetközi határátkelő nevének egybemosásaként lehet zavaró. A nagyobb nehézséget a КPP betűszó jelent(het)i, mely az ukrán Контро́льнопропускни́й пункт (КПП, ellenőrző pont) rövidítésének latin betűs átirata, s a latin betűs írásmódban is értelmezhetetlen a külföldi turisták számára a kulturális ismeretek hiányának tekintetében. (Csernicskó 2018: 119, 7. ábra)

\section{7. ábra. Határátkelőkről informáló útjelző tábla Beregszász központjában}

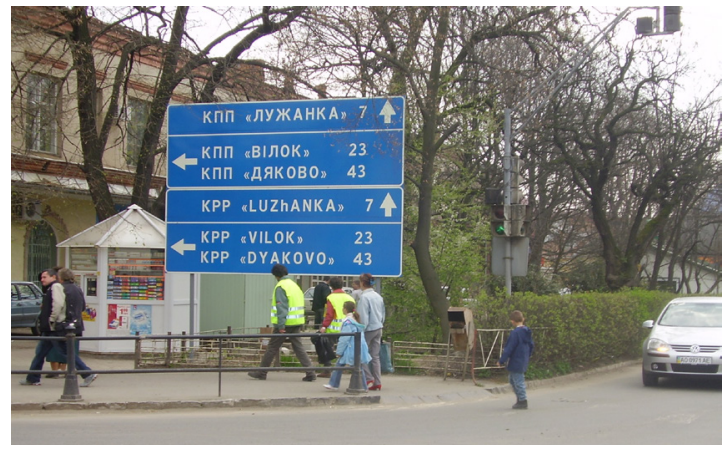

Forrás: Csernicskó 2018: 119. 


\section{TEMATIKUS TANULMÁNYOK - Kárpátalja társadalma}

Kárpátalja turisztikai vonzerői és látványosságai közül az épített örökség kategóriában jelentősen kiemelkedik a Munkácsi vár és az Ungvári vár. A Munkácsi Városi Tanács sajtószolgálatának közleménye szerint Munkács várát a 2017-es évben rekordszámú, 282460 fő kereste fel (URL8). Az Ungvári vár esetében nem áll rendelkezésre látogatói létszám, azonban közel hasonló lehet a Munkácsi váréhoz.

A Munkácsi vár bejáratánál jelenleg ukrán egynyelvű felirat jelzi, hogy a Munkácsi Történelmi Múzeumban járunk, míg a vár nem is kerül említésre. Korábban szintén egy ukrán nyelvủ intézményi névtábla, s alatta pedig egy a Rákóczi Örökségút pályázati projekt keretében készült négynyelvű (ukrán, angol, magyar, szlovák) Munkács várának névtáblája volt látható. Ezen a táblán viszont a vár ukrán neve nem megfelelően lett feltűntetve, hiszen a hivatalos neve, а Замок Паланок helyett Мукачівський замок volt olvasható. Az állam által kihelyezett hivatalos névtábla jelenlegi formában (barnás színezet) kevésbé illik bele az ukrán nemzetállam hangsúlyozásába, mint elődje (kék-sárga nemzeti színű), de a négynyelvủ tábla eltűnése viszont mindenképpen hátrányosan érinti az idelátogató külföldi turisták informálódását (8. ábra).

\section{8. ábra. A Munkácsi váron lévő névtáblák napjainkban (balra) és 2012-ben (jobbra)}
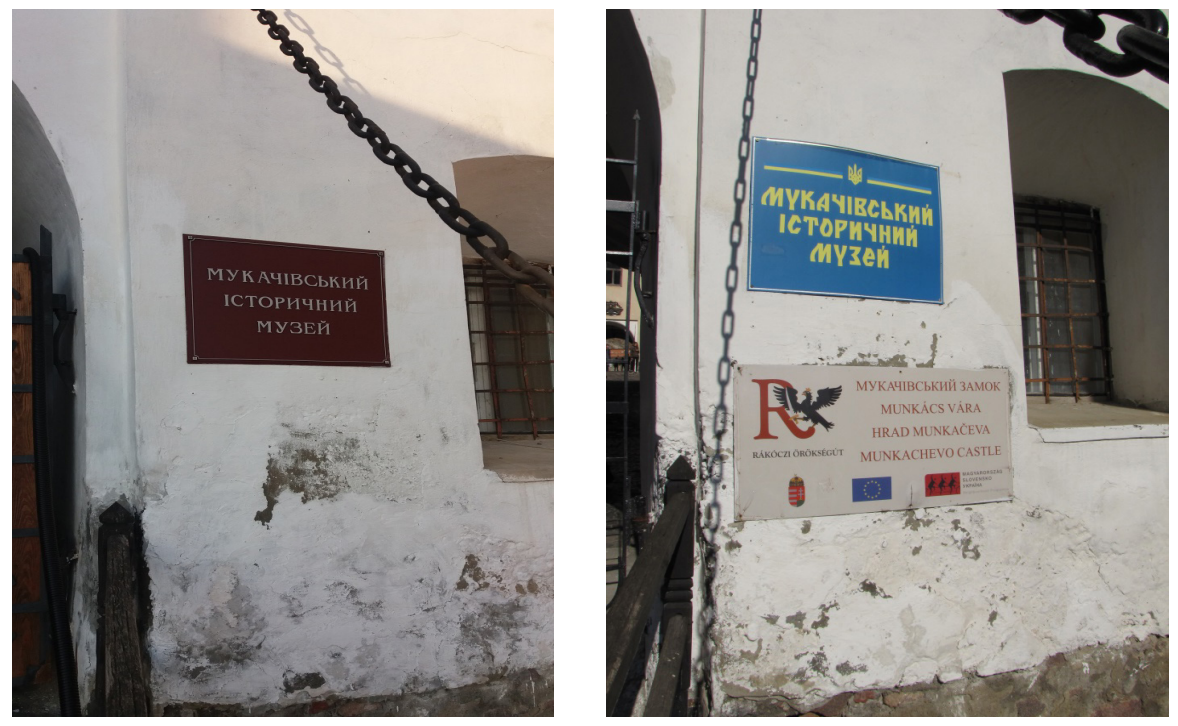

Forrás: Saját fotók

Az Ungvári vár, pontosabban a benne múködő Lehoczky Tivadar Kárpátaljai Helytörténeti Múzeum névtáblája ukrán és angol nyelvű, s a vár hídjától jobbra lévő információs reklámtábla is e két nyelven hirdeti mind e múzeumot, mind pedig ma- 


\section{TEMATIKUS TANULMÁNYOK - Kárpátalja társadalma}

gát az Ungvári várat. A várfalon lévő múzeum névtáblája alatt szintén két nyelven kapott helyet a nyitvatartási idő (9. ábra).

9. ábra. Névtábla és reklámtábla az Ungvári vár előtti plakáton (balra) és a várfalon (jobbra)

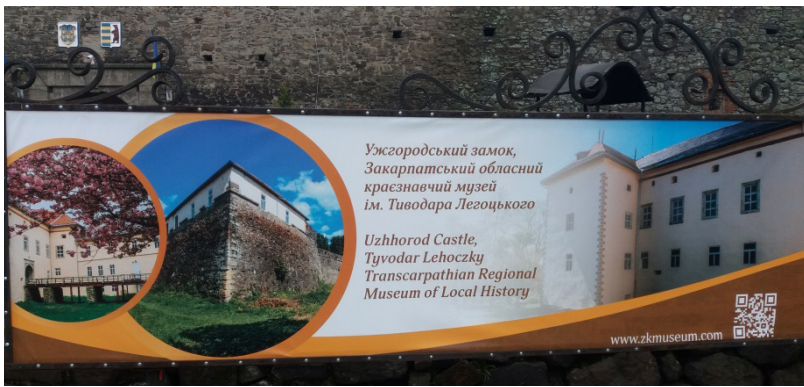

Forrás: Saját fotók

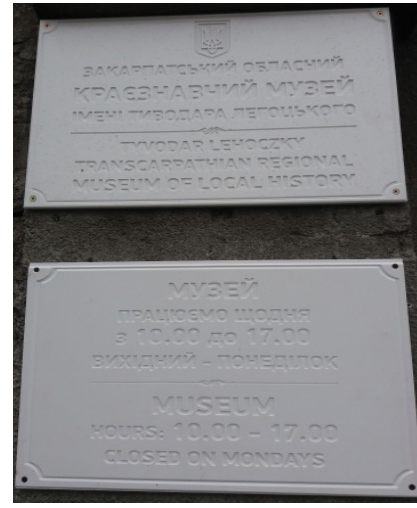

A Munkácsi várban a bejáratnál a belépőjegyek ártájékoztatója kizárólag államnyelven van feltûntetve, míg az Ungvári vár bejáratánál ukrán és angol nyelvű tájékoztató olvasható. Viszont már az Ungvári várban is csak államnyelven olvasható a kedvezményre jogosultak megnevezése, illetve azon információ is, hogy a 2018-as év első napjától már magasabb áron lehet csak belépőjegyet váltani a várba. Vagyis míg a Munkácsi várban már a belépőjegyek árának böngészésénél elakadhat egy külföldi turista, addig Ungváron ugyan jól tájékozódik az árakról, de az esetleg rá is érvényes ingyenes belépési lehetőségről már nem (10. ábra).

Mindkét vár belső terében eltérőek az információs tájékoztatások. Viszonylag sok hivatalos útbaigazító és információ tábla érhető el ukrán és angol nyelven (8. ábra felső sorának 1., alsó sorának 2 . képe). De az információs táblák egy jelentős része még most is csak egynyelvű ukrán (8. ábra alsó sorának 1. képe). Az Ungvári vár kiállítótermeiben minden információ csakis ukrán nyelven áll rendelkezésre a várat önálló felfedezéssel megismerni vágyó külföldiek számára. Ez alól kivétel a 2017 végén nyílt legújabb állandó kiállítás, amely a Magyar Kormány támogatásával Kárpátalja történelmét a 8. századtól 1920-ig mutatja be három nyelven: ukránul, magyarul és angolul. A Munkácsi várban hasonló, nem állami kezdeményezések keretében megvalósuló állandó kiállítások tekinthetők meg, mint például ukrán, magyar, angol nyelven a Kazinczy emlékszoba, a Rákóczi emlékszoba és a lovagterem. Ez utóbbi két kiállítás bejáratánál ukrán, magyar, angol és szlovák nyelvű tábla jelzi, hogy mit is találhatunk a teremben (8. ábra felső sorának baloldali képe). Viszont érdekes, hogy a „háromnyelvű” Rákóczi emlékszobában csak ukránul tájékoztatják a turistákat, hogy a kiállítási tárgyakat megérinteni tilos. 
www. metszetek.unideb.hu

\section{TEMATIKUS TANULMÁNYOK - Kárpátalja társadalma}

\section{0. ábra. Belépőárak tájékoztatói}

az ungvári (balra és középen) és a munkácsi (jobbra) várakban
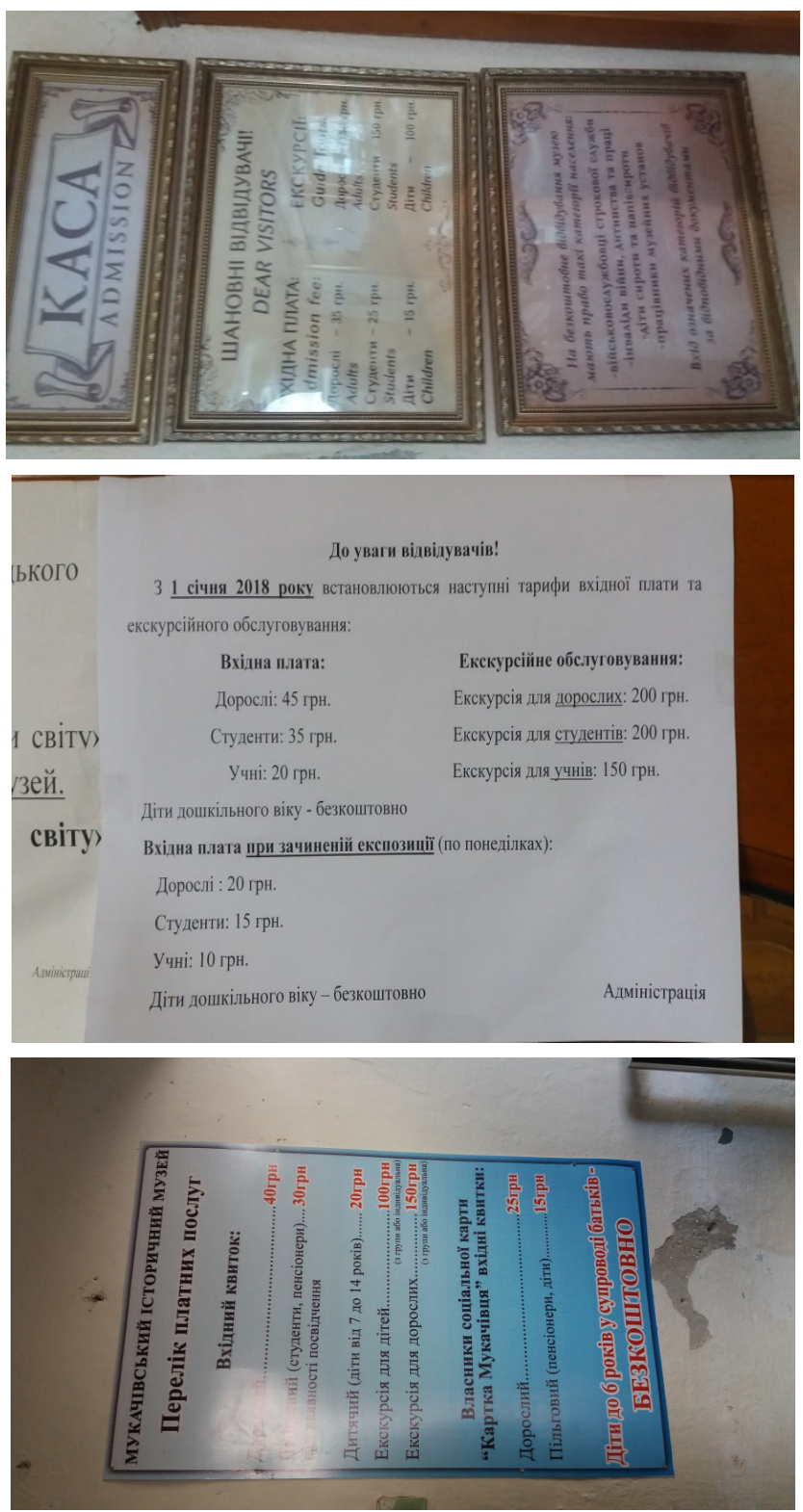

Forrás: Saját fotók 
www. metszetek.unideb.hu

\section{TEMATIKUS TANULMÁNYOK - Kárpátalja társadalma}

11. ábra. Információs táblák az ungvári (alsó sor) és munkácsi vár (felső sor) belső tereiben
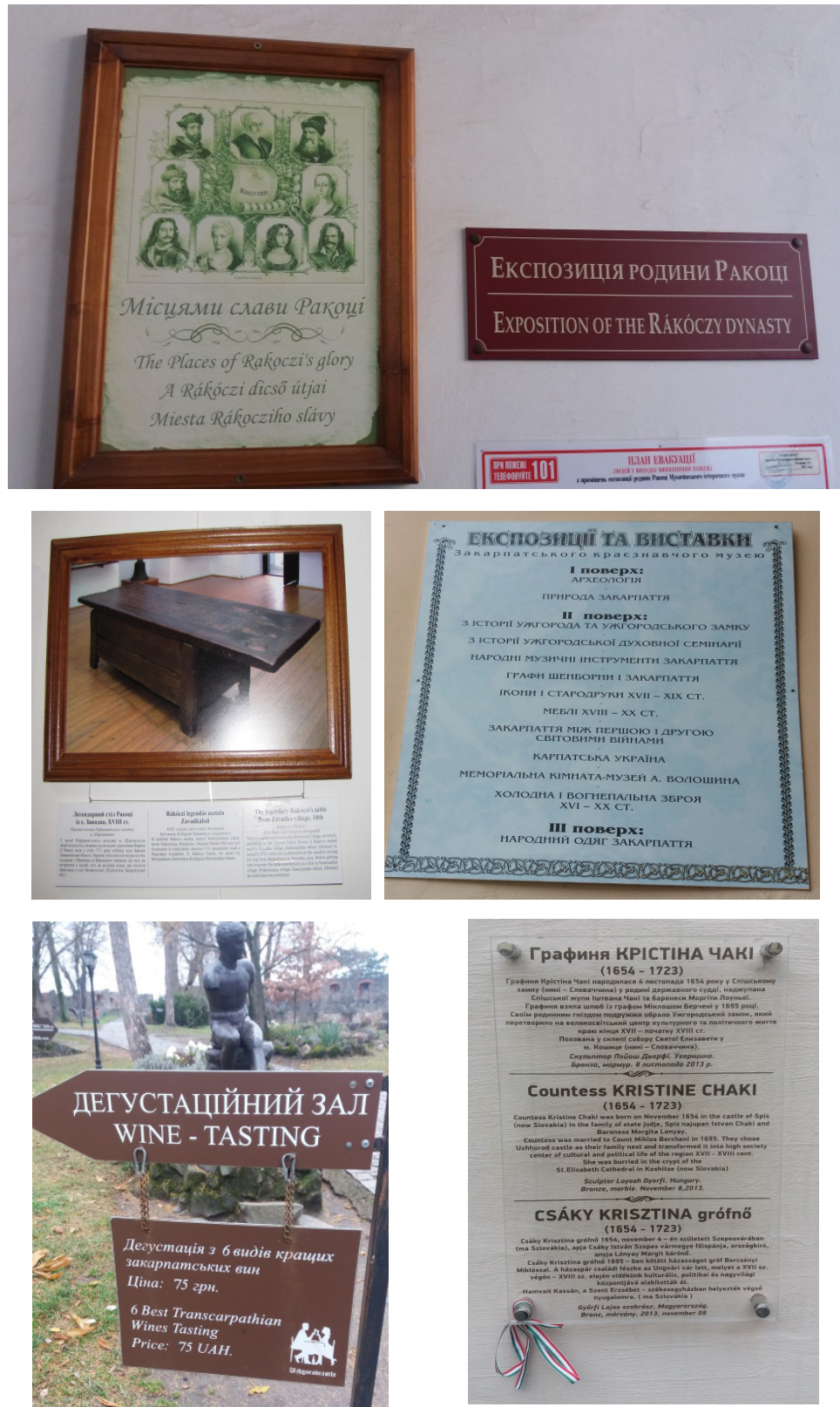

Forrás: Saját fotók 


\section{TEMATIKUS TANULMÁNYOK - Kárpátalja társadalma}

A magyar nyelv megjelenése mindkét vár esetében a magyar vonatkozású emléktáblák, emlékművekhez kapcsolódóan jelenik, amelyet magyarországi támogatásból létesítenek (pl. 11. ábra alsó sorának jobboldali 3. képe). Az ilyen típusú emléktáblákból a Munkácsi várban található jelentősebb számban.

A Munkácsi vár esetében mindenképpen érdemes említést tenni a felső várudvarban helyet foglaló Rákóczi pince kereskedelmi egységről, melynek csupán a neve jelenik meg magyar nyelven, de a reklámtábla többi része cirill betűs. (12. ábra)

12. ábra. A Munkácsi várban lévő Rákóczi pince csalogatója a pince bejáratánál

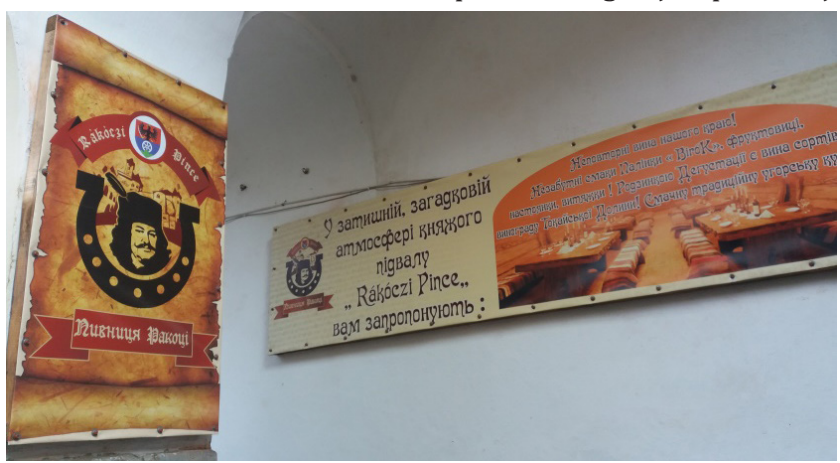

Forrás: Saját fotó

A két váron kívül természetesen számos kisebb-nagyobb érdeklődésnek örvendő épített örökségi látnivaló található Kárpátalján, melyek többségénél csak ukrán nyelvű információs táblák olvashatók. A többségében ukránok által lakott területen ritkán fordul elő ukrán és angol kétnyelvű felirat, míg a román kisebbség által lakott területen ukrán és román, illetve a magyar kisebbség által lakott területen ukrán és magyar nyelvű tájékoztatók és információs táblák is találhatók. De a többségében ukrán nyelvű információs táblák mellett találkozhatunk három vagy annál több nyelvủ kiírásokkal is (13. ábra).

A Verecke-hágón a közút mellett lévő, sok átalakítást megélt, a Kárpát-Ukrajna szicsgárdistáinak ${ }^{9}$ emléktemetőjét két nagy információs tábla is övezi: egy nagyméretű ukrán nyelvű, majd egy ugyanolyan méretű angol, lengyel és magyar nyelvű (14. ábra). A négynyelvü információs táblák mindenképpen örvendetes tényként szolgálnak, hiszen a Vereckei-hágót a honfoglalás emlékhelyeként sok magyar turista, illetve mint egykori lengyel határvéget, egyre több lengyel turista keresi fel, s így ők is informálódhatnak a létesítményről. Az más kérdés, hogy a rajta szereplő tények az ukrán történelem szemszögéből szemléli a dolgokat, s a többi érintett nemzet

\footnotetext{
${ }^{9}$ Kárpát-Ukrajna fegyveres alakulata.
} 


\section{TEMATIKUS TANULMÁNYOK - Kárpátalja társadalma}

történészei valószínúleg valamelyest más képet festenének, hiszen az itt történt események közös feldolgozása még nem történt meg.

13. ábra. Egy-, két- és háromnyelvű információs tábla az épített örökségeknél
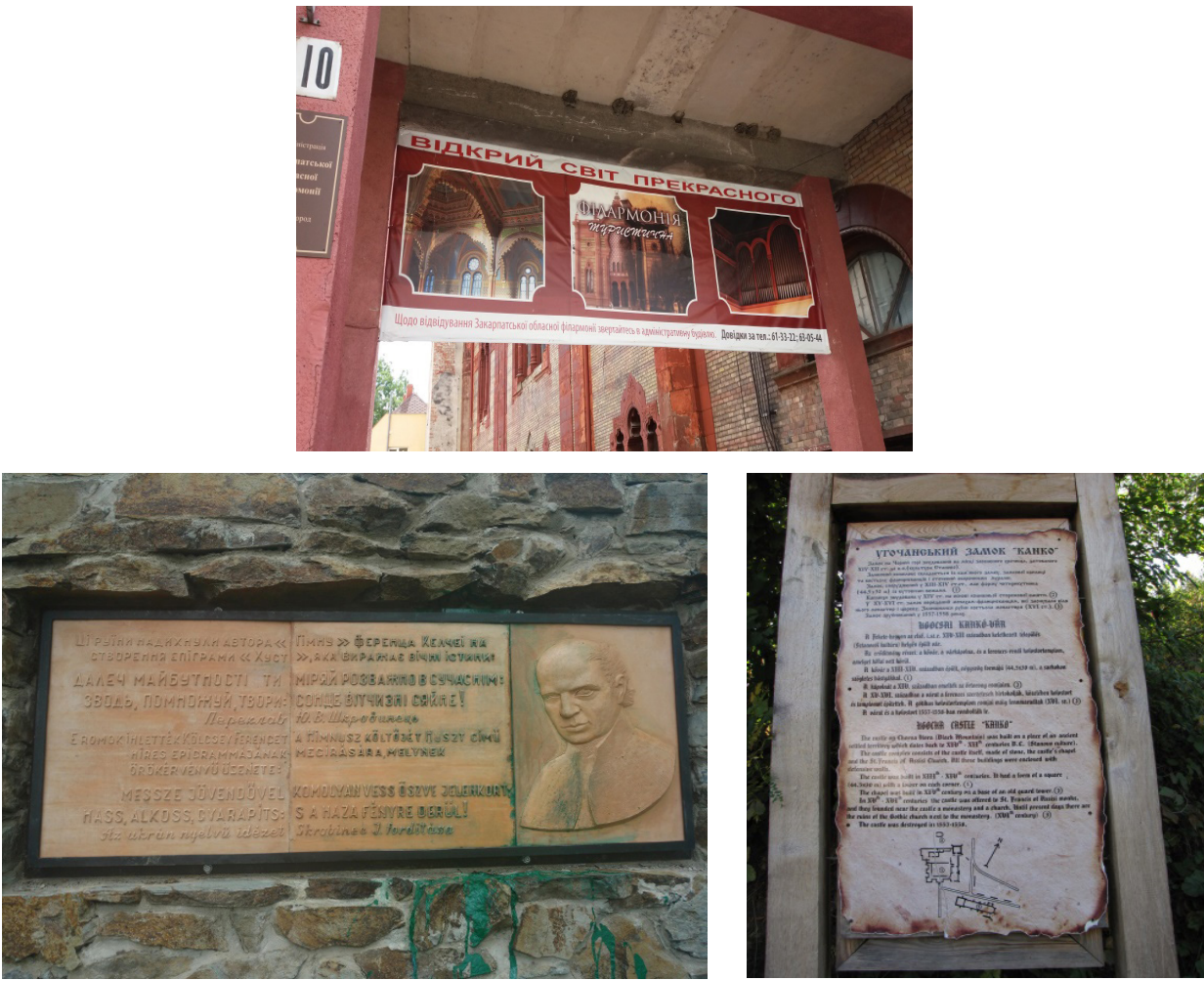

Forrás: Saját fotók

Kárpátalja természeti vonzerői közül még a turisták által legjobban kedvelt helyeken is zömében csak egynyelvű ukrán információs táblák tájékoztatják az oda látogatókat. Az évente több tízezer turistát vonzó Szinevéri-tónál, a Nárciszok-völgyénél, a Sipot-vízesésnél, Sajáni-tónál stb. az államnyelvi feliratokon kívül nem nagyon találunk idegen nyelvű információkat, pedig e látványosságokat jelentős számú külföldi turista keresi fel a nagy létszámú ukrajnai belső turizmuson kívül. Ha az ukrán nyelven kívül mégis találkozunk más nyelvű felirattal, akkor az általában a kereskedelmi és szolgáltató egységeknél fordul elő. A 14. ábrán látható, hogy a Szinevéri-tó partján található étterem négy nyelven üdvözli a hozzá betérőket. Azonban az ukrán Ласкаво просимо! kifejezést magyarul az Üdvözöljük! helyett Fogadtatás!-nak fordítják. 
www. metszetek.unideb.hu

\section{TEMATIKUS TANULMÁNYOK - Kárpátalja társadalma}

14. ábra. A Vereckei-hágón lévő Kárpát-Ukrajna emléktemetőjének információs táblái
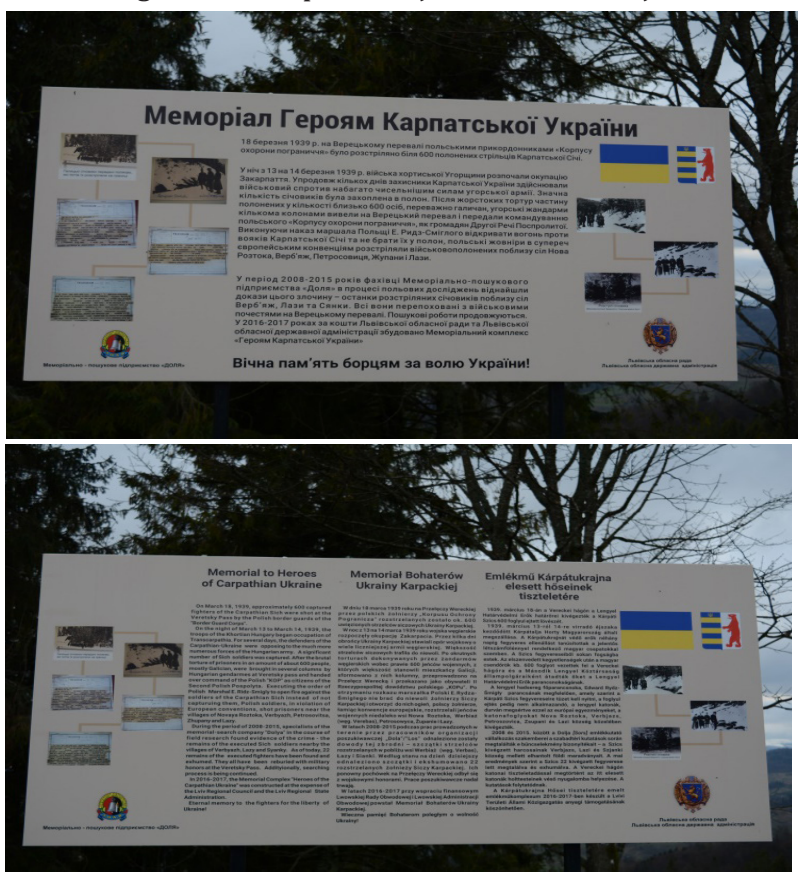

Forrás: Saját fotók

A kisebb jelentőségű természeti látványosságok esetében, mint például a Feketeés Fehér-Tisza összefolyása, Vereckei-szoros stb., a legtöbbször még az ukrán nyelvü információs tábla is hiányzik.

15. ábra. Szolgáltató egység négy nyelvű üdvözlőtáblája a Szinevéri-tónál

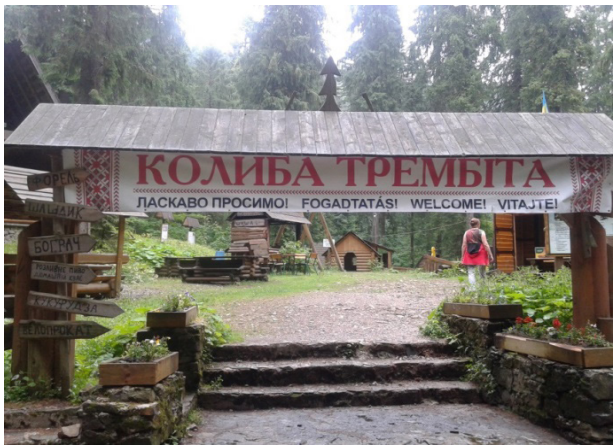

Forrás: Saját fotó 


\section{TEMATIKUS TANULMÁNYOK - Kárpátalja társadalma}

A hegyi túrákra vállalkozó turistákat informáló táblák két nagy csoportra bonthatók. A részletesebb leírást tartalmazó táblák többségében csak ukrán nyelven olvashatók. Viszont a túraútvonalakon elhelyezett információs táblák kétnyelvúek: az ukrán mellett angol vagy cseh (szlovák) nyelven is feltűntetik a hegycsúcsok, tavak neveit.

16. ábra. Hegyvidéki turistaútvonalak kétnyelvű jelzőtáblái: balra ukrán-szlovák/cseh, jobbra ukrán-angol nyelvű
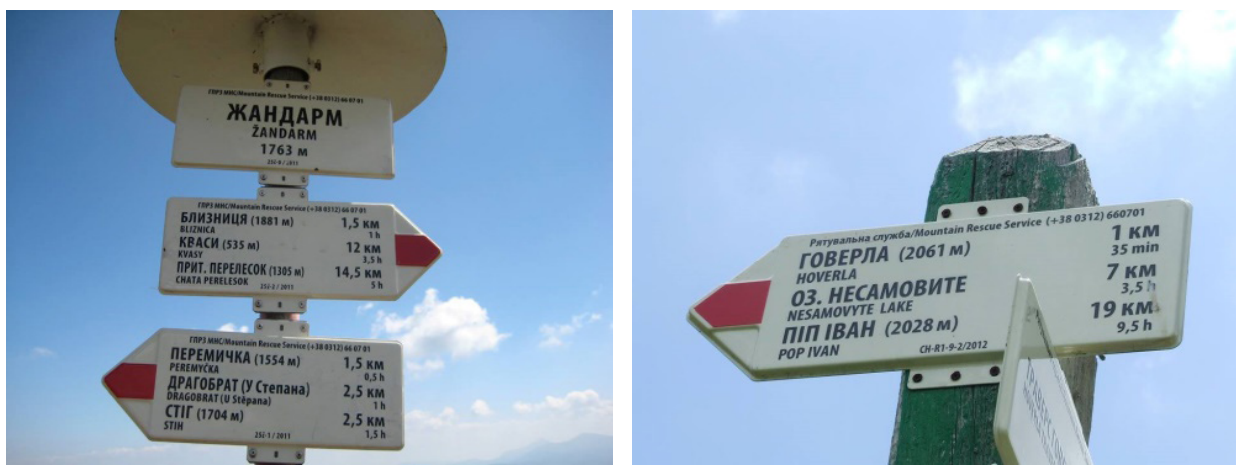

Forrás: Bíró András fotói

\section{Egy turisztikai vonzáskörzet és a nyelvi tájkép változása}

A turizmus nyelvi tájképre gyakorolt hatása egész Kárpátalja területén nagyon nehezen mutatható ki és kisebb vonzáskörzetekben más és más hatás és jelenségvonzat jelentkezik, jelentkezhet.

Nagyon jó példa az Árpád-vonal, mint egykori Magyar Királyság határvédelmi rendszerének Kárpátalja területén megmaradt bunkerei, mint turisztikai látványosság. Ezek közül a legnagyobb és utóbbi időben leglátogatottabb tagja a felsőgerebeni (Верхня Грабівниця) parancsnoki bunker, amelyet egy magánvállalkozó üzemeltet. A bunker környékén nem találkozunk sem magyar, sem angol nyelvű feliratokkal. De a bunker belsejében lévő információk is csak ukrán nyelven érhetők el, akárcsak az egyre jobban kiépülő bunkeren kívüli szolgáltatóegységekben. Az Uzsoki-hágó irányába haladva Malomrét (Жорнава) közelében lévő bunkerrendszernél viszont három nyelven (ukrán, angol és magyar) is olvasható a bunkerek és a védelmi rendszer leírása. 


\section{TEMATIKUS TANULMÁNYOK - Kárpátalja társadalma}

17. ábra. Az Árpád-vonal malomréti bunkereinek egyik háromnyelvű táblája

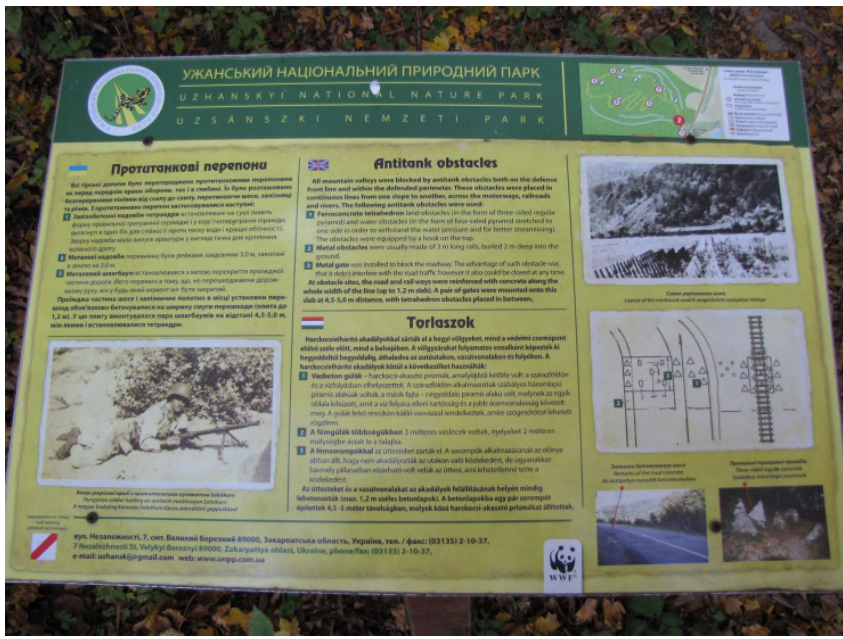

Forrás: Saját fotó

Mint ahogy az Árpád-vonal turisztikai hasznosítása és információs ellátottsága vonzáskörzetenként változik a nyelvek hozzáférhetőségét tekintve. Ezért az alábbiakban egy konkrét vonzáskörzet példáján mutatom be, hogy a turizmus fellendülése milyen változásokat hozott a nyelvi tájképben. A vonzáskörzet turisztikai vonzerejét a Kaszonyi-hegy lábánál lévő „Kaszony termálvíz” (továbbiakban Kaszonyi Termálfürdő), illetve az Eko-termál termálfürdők alkotják.

\section{A vizsgált aspektus és előzményei}

A nyelvi tájképben bekövetkezett változás bemutatása a 2011 és 2012 folyamán a Hodinka Antal Nyelvészeti Kutatóközpont munkatársai által a Beregszászi, Ungvári, Nagyszőlősi és Munkácsi járás legalább 50\%-ában magyarok lakta településein (Molnár-Molnár 2005) végzett kutatás során készített digitális fotók segítségével felmért nyelvi tájkép, és a magyar nyelv megjelenésének (vagy éppen hiányának) dokumentálása az egyes helységek szimbolikus terében (továbbiakban első vizsgálat); illetve a 2016 februárja és szeptembere között a Beregszászi járási Zápszony (magyarok aránya 92,1\%), Mezőkaszony (magyarok aránya 89,3\%) és Nagybégány (magyarok aránya 87,5\%) településeken (Molnár-Molnár 2005) a köztereken elhelyezett lakossági és egyéb hirdetésekről készített fotógyűjtemény (továbbiakban második vizsgálat) összevetésével történt. A vizsgálattal célom volt rávilágítani a három településen és környezetében bekövetkezett gazdasági változások, különös tekintettel a Kaszonyi Termálfürdőben, illetve az Eko-termál termálfürdőben elvég- 


\section{TEMATIKUS TANULMÁNYOK - Kárpátalja társadalma}

zett fejlesztési projektnek köszönhetően megnövekedett belső ukrajnai turisztikai kereslet nyelvi tájképre gyakorolt hatásaira.

A települések nyelvi tájképében történt változás a vonzáskörzet turisztikai kínálatában bekövetkezett változásoknak köszönhetően indultak meg. A Kaszonyi-hegy lábánál feltárt termál kutaknak köszönhetően 1995-ben megnyitottak egy kétmedencés fürdőhelyet, amely sokáig látta el a helyiek és a főként kárpátaljai turisták igényeit. Ezen időszakban sem a létesítmény területén, sem pedig a környező falvakban nem igazán találkozhatunk a turizmust és azok szolgáltatásait népszerüsítő hirdetéssel vagy szóróanyaggal.

2006-ban a területnek és a létesítménynek új tulajdonosa lett, aki 2012-ben az ötéves fejlesztési projekt keretében jelentős beruházást végzett. Az elvégzett és napjainkban is tartó fejlesztéseknek köszönhetően jelentősen megnövekedett fürdőt felkereső turisták száma, különösen a Kárpátokon túlról érkező belső-ukrajnai turisztikai kereslet. Az Eko-termál termálfürdő területén megindult fejlesztéseknek köszönhetően 2015-ben az egykori gyógyszanatórium területén is megindult a vendégek fogadása. Ez szintén hozzájárult a turisták számának növekedéséhez. A megnövekedett - szállást, szórakozási lehetőségeket kereső - turistáknak köszönhetően a szolgáltatási szférában meginduló folyamatok a közösségi terek nyelvi képét is átfestették. Az egyre növekvő turistalétszámmal egyre többen kezdtek el foglalkozni magánházaikban vendégfogadással, melynek eredményeként számos reklám, információ és szálláskínálat jelent meg a turisták információval való ellátása érdekében.

\section{A turizmus hatása a nyelvi tájképre a vizsgált területen}

Csernicskó és Laihonen (2016) a kaszonyi termálfürdő nyelvi tájképének elemzésekor megállapítják, hogy a Kárpátalja magyarok lakta vidékére érkező szláv ajkú turisták zöme az orosz nyelvet használja, s ennek tulajdonítják az orosz nyelvű feliratok megjelenését is. Az orosz nyelv a posztszovjet térségek közül nem csupán Ukrajnában (Kárpátalján) jelenik meg a turizmusban, hanem újra kulcsszerephez jut Magyarországon (Bátyi 2014) és a balti államokban (Pavlenko 2015, Csernicskó 2017).

Az első vizsgálat eredményei alapján elmondható, hogy vizsgált három településen a hivatali élet színterén a nyelvi tájkép többnyire kétnyelvű. A településeken található közintézmények és hivatalok, azok vezetőinek, közalkalmazottainak nevei többnyire ukrán és magyar nyelven is olvashatók. A településekre érkezve azok helységnévtáblái kétnyelvűek voltak, míg az utcanév-táblák csak néhol voltak kihelyezve, de minden esetben kétnyelvű táblákkal találkoztunk. A helyi lakosság és a Beregszászi járás területén működő vállalatok hirdetései ebben az időszakban főként magyarul, vagy esetleg mindkét nyelven kerültek kihelyezésre. A csak ukrán nyelvü hirdetés-kihelyezés főként megyei vagy más járásokban működő cégek, hivatalok 


\section{TEMATIKUS TANULMÁNYOK - Kárpátalja társadalma}

hirdetéseinél, hivatalos tájékoztatásainál volt megfigyelhető (Karmacsi 2014, Látható kétnyelvűség 1., Látható kétnyelvűség 2.).

A települések helységnév-névtáblái, az intézmények és hivatalok, azok vezetői, közalkalmazottai nevének kihelyezése tekintetében az első vizsgálathoz képest a nyelvi arányokban nem történt jelentős változás. Kivétel ez alól Zápszony utcanév-táblái, hiszen 2016-tól minden utcában kétnyelvú névtábla hirdeti az utca nevét.

Mindezekhez képest viszont jelentős változás figyelhető meg a nyelvi tájkép esetében a helyi lakosok és a helyi vállalkozók által kihelyezett hirdetéseknél. Míg korábban jellemzően magyar nyelven tettek ki hirdetést a vizsgált települések lakói, addig az ismételt vizsgálatnál már a hirdetéseknél jelentősen megnövekedett a csak ukrán nyelven kihelyezettek aránya. Ezen hirdetések szinte mindegyike közvetlenül vagy közvetetten összekapcsolódik a turizmushoz, amelynek a legfőbb jellemezője a megnövekedett belső-ukrajnai turisztikai kereslet. A legszembetűnőbb és közvetlenül a turizmus megnövekedésével összefüggő hirdetések a szoba/házrész/ház kiadó hirdetmények megjelenése, amelyek igazodva a kereslethez, szinte csak ukrán/orosz nyelven jelentek meg a települések nyelvi tájképében. Zápszonyban 19 esetben hirdetik a kiadó szobákat kizárólag ukrán/orosz nyelven, míg Kaszonyban mindössze hat hirdetéssel találkozhatunk, melyből egy ukrán-magyar nyelven került kihelyezésre. Ez utóbbi azért érdekes, mivel a kihelyezője csak nemrég települt Kaszonyba. A Kirovográdból (napjainkban Kropivnickij) áttelepült házaspár elmondta, fontosnak tartották, hogy a helyi viszonyoknak megfelelően magyarul is rákerüljön a hirdetés szövege. Zápszony esetében főként a termálfürdőkhöz közelebb eső településrészen hirdetik többen kiadó szobájukat, jelentősen megváltoztatva a településrész nyelvi tájképét.

18. ábra. Kiadó szobák kétnyelvű hirdetése Kaszonyban (balra), ukrán egynyelvű pedig Zápszonyban (jobbra)
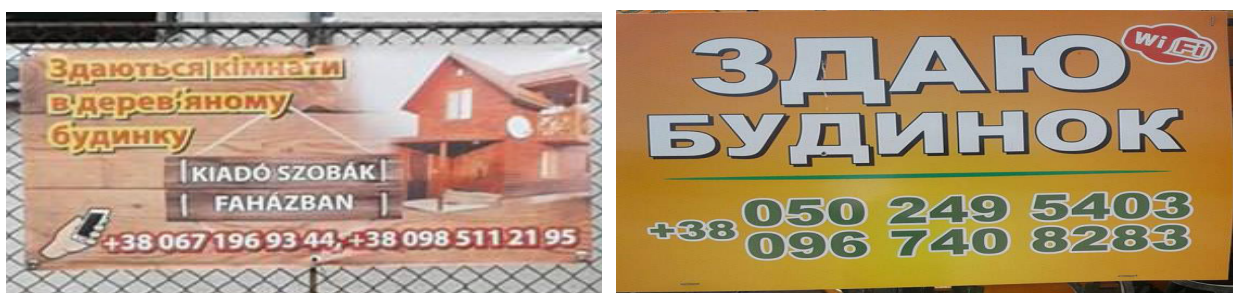

Forrás: Saját fotók

Nagybégányban a kiadó szobákat, házakat csak ukrán és orosz nyelven hirdetik a lakosok. Mindössze az egyik ukrán nyelvű hirdetés alján olvashatjuk az angol ROOMS feliratot is. A hirdetésben megjelenő angol nyelvű szövegrész valószínúleg itt sem a nemzetközi nyelven történő információszolgáltatást szolgálja, hanem in- 


\section{TEMATIKUS TANULMÁNYOK - Kárpátalja társadalma}

kább utal arra, mint amit Csernicskó István (2017) is említ tanulmányában, miszerint ezzel csak a nyugtai színvonalra próbálnak asszociáltatni a szállást keresőkkel.

Mindhárom településen megfigyelhető, hogy az ukrán standardban a kiadó szoba/ház értelemben használt ЗДАЮ, ЗДАЮТЬСЯ kifejezések mellett előfordul а ВИДАЮ kifejezés is, amely a magyar nyelv hatására létrejött tükörfordítás (19. ábra).

19. ábra. A szoba/ház kiadó kifejezés változatai a hirdetményekben
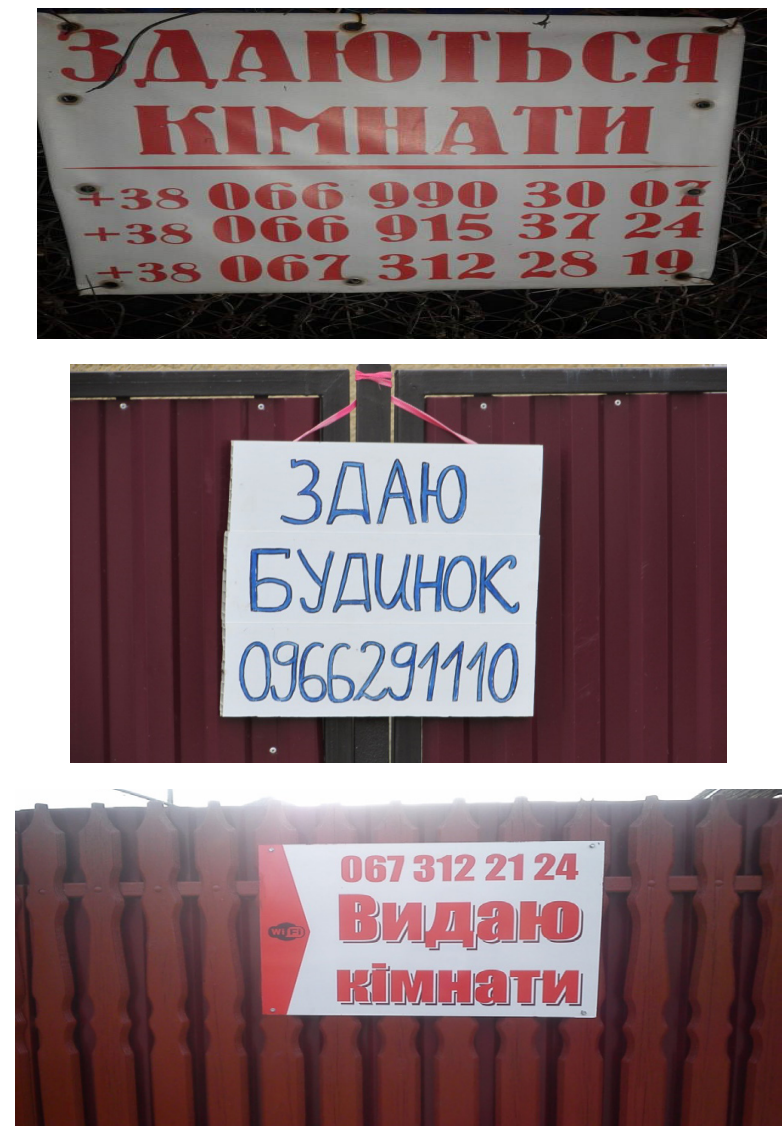

Forrás: Saját fotók

A kiadó szobák hirdetésében érvényesül a turisztikai szolgáltatásokra jellemző szezonális jelleg. Például Nagybégányban februárban mindösszesen 14 helyen találkoztunk kiadó szobát hirdető felirattal, míg júliusra ez a szám 43-ra duzzadt fel. Azonban szeptember végére már újra csökkenést mutatott, s csupán 31 hirdetéssel 


\section{TEMATIKUS TANULMÁNYOK - Kárpátalja társadalma}

találkoztunk. Ezen adatok szerint is a turisztikai (gazdasági) változás nyelvi tájképre gyakorolt hatása megfigyelhető, hiszen a vendégek elmaradásával, vagyis a gazdasági motiváció csökkenésével együtt csökken a nyelvi térben elhelyezett hirdetések száma. A fentiek alapján elmondható, hogy egy éven belül is jelentős változást mutat egy-egy település/terület nyelvi tájképe a turistaforgalom, s így a turizmus hatása tekintetében.

Szintén a szláv ajkú turisztikai kereslet megnövekedéséhez próbálnak igazodni a boltok, éttermek, kávézók és kereskedelmi szálláshelyek reklám- és információs táblái. A 2011 után kihelyezett hirdetések, cégtáblák szinte mindegyike csak ukrán nyelven van kifüggesztve. A szolgáltatóipar és vendéglátás hirdetései a gazdasági realitások mentén jelennek meg a települések nyelvi tájképében (Csernicskó 2017), hiszen a vendégkör 95\%-a szláv ajkú, ezért jellemzően a reklámok és hirdetések is e nyelven célozzák meg a vendégeket.

20. ábra. Célközönség szerinti nyelvhasználat a kaszonyi Kulacs étterem reklámjain: a falu területén (balra) és a felsőbbrendű főút mentén (jobbra) elhelyezett reklámtáblák
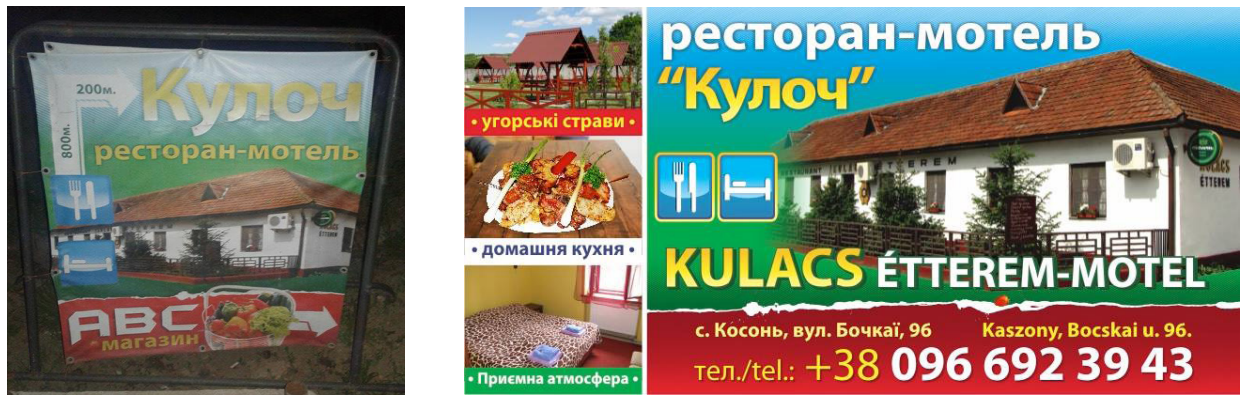

Forrás: Saját fotók

A mezőkaszonyi Kulacs étterem-motel a célközönség szerint helyezte ki a reklámanyagait (19. ábra). A településen kívüli felsőbbrendű főút mentén az óriásplakáton, ahol távolabbi települések magyar lakosai is láthatják, két nyelven hirdetik az éttermet. Ezzel szemben Zápszonyban és Mezőkaszonyban csak ukrán nyelven helyezték el hirdetésüket. Mivel mind a helyiek, mind pedig a zápszonyiak jól ismerik az éttermet, ezért az egynyelvű ukrán reklámanyag egyértelműen az ideérkező turisták részére készült, hiszen mindkét település jelentős turistaforgalmat bonyolít le. Ráadásul a zápszonyi hirdetés csak azon a településrészen jelent meg, amelyik közelebb esik a termálfürdőhöz, jelezve ezzel a célközönséget is.

A munkahirdetésekben is elvárásként jelenik meg a pincérekkel, boltosokkal szemben a legalább kommunikáció szintű ukrán/orosz nyelvtudás. A Kaszonyi Termálfürdő munkahirdetéseiben szintén alapkövetelményként jelenik meg az ukrán/ orosz nyelvismeret. 


\section{TEMATIKUS TANULMÁNYOK - Kárpátalja társadalma}

2016-ban a három településen összesen 17 ingatlant próbáltak meg értékesíteni. Zápszonyban az eladó ingatlanok mindegyikét szláv nyelven kínálták, míg Nagybégányban többnyire magyarul. Mezőkaszonyban a hét eladó ház közül 3-at csak ukrán nyelven, 4-et pedig magyar és ukrán nyelven hirdettek eladásra. Az eladó házak ugyan nem közvetlenül kapcsolódnak a turisztikai kereslet növekedéséhez, de közvetetten mégis, hiszen számos belső-ukrajnai személy vásárol házat hétvégi nyaralónak, illetve a kelet-ukrajnai konfliktus következtében akár végleges lakhatás céljával is.

Az eladó házak hirdetései közül 6 esetében a szláv nyelvű felirat kevert (hibrid) megoldással készült. Az 5. képen látható három kiírás is jól szemlélteti a kevert megjelenést, hiszen a ДОМ kifejezés egyértelműen az orosz nyelvből való, míg а ПРОДАЄТЬСЯ pedig az ukrán nyelvben használatos (21. ábra, jobb felső hirdetés).

21. ábra. A HÁZ ELADÓ hirdetés szláv nyelvi változatai (felül: balra ukrán nyelvű, jobbra kevert nyelvű, alul: orosz nyelvű
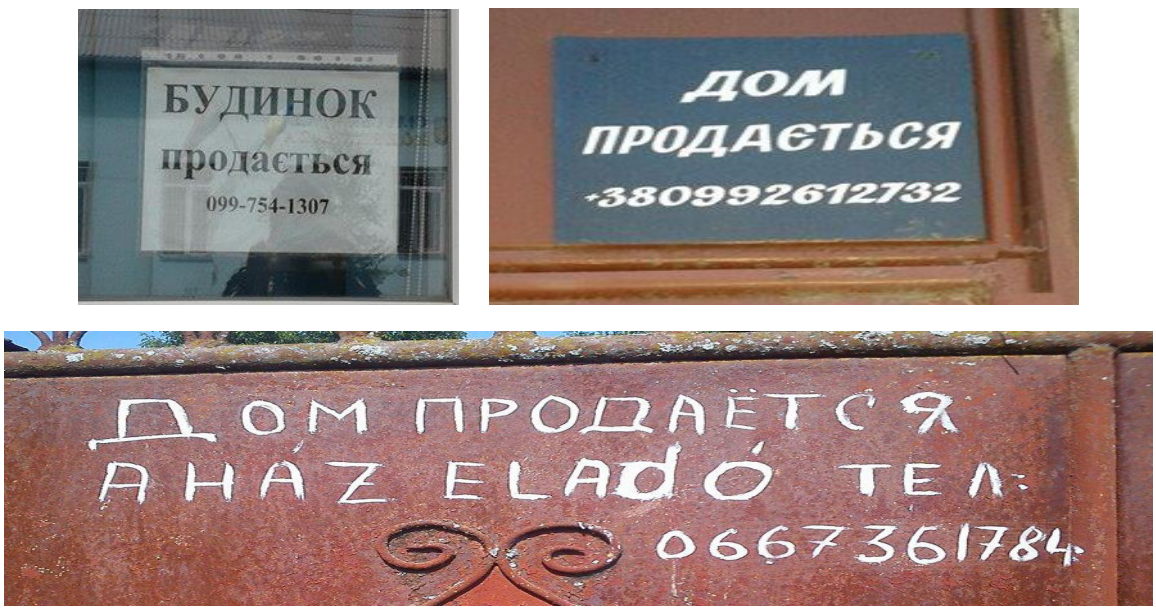

Forrás: Saját fotók

\section{Összefoglalás}

Kárpátalja épített és természeti turisztikai vonzerőinek legtöbbje a volt Szovjetunió idején kialakult „bemutatási hagyományokkal” várja még napjainkban is a területre érkező vendégeit, amely a zömében belső turizmusra épített. Ennek köszönhetően az információs ellátottság tekintetében a szovjet mintára alapuló egynyelvű ellátottság a jellemző még napjainkban is annyi különbséggel, hogy az orosz nyelv szerepét a legtöbb esetben már az ukrán államnyelv vette át.

Viszonylagos előrelépés történt 2012-ben, amikor is számos turisztikai látványosságnál az ukrán mellett főként angol nyelvű tájékoztatók is megjelentek. Azonban e 


\section{TEMATIKUS TANULMÁNYOK - Kárpátalja társadalma}

fellángolás a futball Európa Bajnokság végeztével alábbhagyott. Viszont 2016-tól a Kárpátaljai Megyei Állami Adminisztráció elnökének 426. számú megbízása alapján újabb lendületet kaphat a turisztikai információk többnyelvü hozzáférhetősége a Kárpátalja megyei turisztikai és üdülési fejlesztési programja a 2016-2020 közötti időszakra turisztikai fejlesztési programnak köszönhetően, melynek egyértelmű hozománya lehet az előírt turisztikai virtuális és vizuális információk több nyelven való elérhetővé tétele. A megye vezetése tehát a turisztikai és üdülési program keretében az államnyelv turisztikai információs térben betöltött hegemóniájának csökkentése révén igyekszik vonzóbbá tenni Kárpátalját a külföldi turisták szemében.

Az épített turisztikai látványosságok két legjelentősebb és leglátogatottabb színhelyén, a Munkácsi és Ungvári várakban a hivatalos információk egy része napjainkban már angol nyelven is megtalálható, azonban az aktuális információközlés nyelve továbbra is az államnyelv maradt, akárcsak a kiállításokon látható tárgyak információs feliratainak többsége. A kevésbé látogatott épített turisztikai látványosságok tájékoztatóinak legtöbbje csak ukrán nyelven jelenik meg. Kivételt képez a magyar kisebbség által lakott területeken lévő, vagy kulturális hagyományaik soraiba tartozó látványosságok, melynél a magyar kisebbség az ukrán nyelv mellett magyarul is megjelenteti az információt.

A természeti látványosságok tekintetében még a látogatottabbaknál is csak egynyelvű ukrán tájékoztatással találkozhatunk, míg a kisebbeknél sokszor még ez is hiányzik.

Ha összességében nézzük a turisztikai látványosságok információs ellátottságát, akkor elmondható, hogy Kárpátalján jelenleg zömében az ukrán nyelv uralja a turisztikai látnivalók nyelvi tájképét. Azonban 2012-ben, és 2016-ban megindult egy folyamat, amely a megye vezetésének irányításával a külföldi turisták érdeklődésének felkeltésére alapozva igyekszik több nyelven elérhetővé tenni a turisztikai információkat. E kezdeményezés jelenleg még gyerekcipőben jár, de ha sikerül elmozdítani a papírról a terveket, s a kivitelezés fázisába léptetni, akkor mindenképpen jelentősebb változásokat eredményezhet Kárpátalja turisztikai látványosságainak nyelvi tájképében.

A megye területénél kisebb turisztikai vonzáskörzetek viszont ennél jóval érzékenyebben reagál(hat)nak a területen végbement turisztikai kínálatbővülésre, vagy akár csökkenésre. A korábbi 2011-2012-es kutatási eredmények és a 2016-ban és 2017-ben elvégzett felmérések alapján egyértelműen kimutatható, hogy a kaszonyi termálfürdők vonzáskörzetében bekövetkezett gazdasági változások milyen hatással vannak/lehetnek egy-egy kisebb térség nyelvi tájképének alakulására. A tanulmány második felében elemzett három település (Nagybégány, Zápszony, Mezőkaszony) a szűk turisztikai vonzáskörzetben megnövekedett turisztikai attrakcióknak köszönhetően jelentős gazdasági irányvonalváltáson ment keresztül, hiszen a lakosok többsége kínálta/kínálja falusi turizmus keretében az idelátogató turisták számára lakását, házát, szobáját. A megjelent turisztikai kereslet és kínálat életre hívta 


\section{TEMATIKUS TANULMÁNYOK - Kárpátalja társadalma}

a turisztikai szolgáltatások hirdetését, a területre látogató turisták információval való ellátását. E hirdetmények többsége azonban a belső-ukrajnai területekről érkező vendégeknek köszönhetően ukrán/orosz nyelven kerül kihelyezésre. 2011 után a boltok, éttermek, szolgáltató egységek névtáblái és reklámanyagai is többségében ukrán/orosz nyelven, jobb esetben a magyarral karöltve kerülnek elhelyezésre. Mindebből következik, hogy egy turisztikai vonzáskörzet gazdasági változásai érzékenyen hat(hat)nak az adott kistérség nyelvi tájképére. De a munkahirdetések azt is alátámasztják, hogy e gazdasági változás nemcsak a nyelvi tájképre gyakorol hatást, hanem a nyelvek megterheltségében is változások figyelhetők meg a többségi nyelv javára, különösen a turizmussal összefüggő szolgáltatóipar tekintetében. Azonban ez utóbbi esetében bármiféle következtetések levonása előtt mindenképpen szükségesnek tartom e probléma széleskörű vizsgálatát.

\section{Irodalom}

Baranyi, B. (szerk.) (2009): Kárpátalja. MTA Regionális Kutatások Központja - Dialóg Campus Kiadó, Pécs - Budapest

Bátyi, Sz. (2014): Hévíz: nyelvi tájkép orosz ecsettel. Alkalmazott Nyelvtudomány XIV, 1-2: 21-34.

Ben-Rafael, E. - Shohamy, E. - Barni, M. (2010): Intorduction. In: Shohamy, E. Ben-Rafael, E. - Barni, M. (eds.): Linguistic Landscape in the City. Multilingual Matters, Bristol:11-28.

Berghauer S. (2012): A turizmus mint kitörési pont Kárpátalján (?). Doktori értekezés. Pécsi Tudományegyetem, Pécs

Csernicskó, I. - Laihonen, P. (2016): Hybrid practices meet nation-state language policies: Transcarpathia in the twentieth century and today. Multilingual, 35, 1: $1-30$.

Csernicskó, I. (2013): Államok, nyelvek, államnyelvek. Gondolat Kiadó, Budapest

Csernicskó, I. (2017): Nyelv, gazdaság, társadalom. Globális nyelvek Kárpátalja magyarok lakta végeinek nyelvi tájképében. In: Márku, A. - Tóth, E. (szerk.): Többnyelvüség, regionalitás, nyelvoktatás. Tanulmányok a Hodinka Antal Nyelvészeti Kutatóközpont kutatásaiból III. „RIK-U”, Ungvár:13-44.

Csernicskó, I. (2018): A kisebbségek nyelvmegtartásáról és gazdasági életképességéről a kárpátaljai nyelvi tájkép tükrében. In: Metszetek, 2018, 1: 119-141.

Fedir, S. - Deák, I. (Федір, Ш. - Деяк, I.) (2010): Закарпатське вино. Ужгород

Fedir, S. - Deák, I. (2016a) Kárpátaljai bor. Ungvár

Fedir, S. - Deák, I. (2016b) Transcarpathian wine. Uzhgorod 


\section{TEMATIKUS TANULMÁNYOK - Kárpátalja társadalma}

Hires-László, K. (2015): Nyelvi tájkép és etnicitás Beregszászon. In. Márku, A. - Hires-László, K. (szerk.): Nyelvoktatás, kétnyelvűség, nyelvi tájkép. Autdor-Shark, Ungvár: 160-185.

Karmacsi, Z. (2014): Település és utcanevek Kárpátalja magyarlakta településein. In: Beregszászi, A. - Hires-László, K. (szerk.): Meszelt falakon túl. II. Rákóczi Ferenc Kárpátaljai Magyar Főiskola, Beregszász: 87-98.

Kárpátalja középkori várai képeslapgyűjtemény (2016) (Набир листивок «Середньовични замки Закарпаття», Виготовлено Студиєю Слово

Kárpátaljai Statisztikai Évkönyv (2016) (Статистичний щоричник Закарпаття за 2016 рик). Ужгород: Головне управтиння статистики у Закарпатський области, 2017

Kárpátalja turisztikai eseményeinek kalendáriuma 2017-es évre (Календар туристичних подий Закарпаття на 2017 рик). Ужгород: Закарпатська облдержадминистрация, Департемент економичного розвитку и торгивли

Kárpátaljaturisztikaieseményeinekkalendáriuma(2018)(Календартуристичнихподий Закарпаття 2018 рик). Ужгород: Закарпатська облдержадминистрация, Департемент економичного розвитку и торгивли

Laihonen, P. (2012): Nyelvi tájkép egy csallóközi és egy mátyusföldi faluban. Fórum Társadalomtudományi Szemle, 14, 3

Landry, R. - Bourhis, R. (1997): Linguistic landscape and ethno linguistic vitality. Journal of Language and Social Psychology, 16: 23-49.

Látható kétnyelvűség 1. Látható és működő kétnyelvűség? A magyar nyelv hivatalos/ hivatali használata a kárpátaljai Beregszászi járásban elméletben és a gyakorlatban, pályázati beszámoló, kézirat

Látható kétnyelvűség 2. Látható és működő kétnyelvűség? A magyar nyelv hivatalos/ hivatali használata a Nagyszőlősi, Munkácsi és Ungvári járásokban elméletben és a gyakorlatban, pályázati beszámoló, kézirat

Molnár, J. - Molnár, D. I. (2005): Kárpátalja népessége és magyarsága a népszámlálási és népmozgalmi adatok tükrében. KMPSZ Tankönyv- és Taneszköztanácsa, Beregszász

Pavlenko, A. (2015): Russian-friendly: how Russian became a commodity in Europe and beyond. International Journal of Bilingual Education and Bilingualism

Rada (2015): Zakarpattya Region. Ukraine Today: Catalog of leading enterprises of Ukraine. [www.rada.com.ua/eng/RegionsPotential/Zakarpattya]

Sass, E. (2008): Kárpátalja Ukrajna turizmusában betöltött pizíciójának vizsgálata. In: Szónoky Ancsin, G. (szerk.): Magyarok a Kárpát-medencében: Tudományos nemzetközi konferencia CD-ROM, Szeged: 465-476. 


\section{TEMATIKUS TANULMÁNYOK - Kárpátalja társadalma}

Sass, E. (2012): A kárpátaljai falusi turizmus múltja, jelene és jövőképe. In: Aubert, A. - Gyuricza, L. - Huszti, Zs. (szerk.): A kultúra turizmusa a turizmus kultúrája. IDResearch Kft. - Publikon, Pécs: 529-549.

Sass, E. (2016): Kárpátalja fesztiváljainak elemzése internetes megjelenésük alapján. In: Jászberényi, M. - Zátori, A. - Ásványi, K. (szerk.): Fesztiválturizmus. Akadémiai Kiadó, Budapest: 368-382.

Tematikus turistautak Kárpátalján (Туристические маршруты Закарпатья), Закарпатськая Обласная Государственная Администрация

Ukrajna Nemzeti Atlasza (2009) [Национальний атлас України Державне науково-виробниче пидприємство «Картография», Київ, 2009]

URL1: Tavaly közel 278 ezren látogattak el a munkácsi várba. 2017.01.04. http:// www.karpatalja.ma/karpatalja/szines/tavaly-kozel-278-ezren-latogattak-el-amunkacsi-varba/ Utolsó letöltés: 2017.11.26.

URL2: Egymillió turista járt idén Kárpátalján. 2017.09.19. http://karpathir.com/ 2017/09/19/egymillio-turista-jart-iden-karpataljan/ Utolsó letöltés: 2017.11. 26.

URL3: Термальні води https://uk.wikipedia.org/wiki/\%D0\%A2\%D0\%B5\%D1\% 80\%D0\%BC\%D0\%B0\%D0\%BB\%D1\%8C\%D0\%BD\%D1\%96_\%D0\%B2\%D0\% BE\%D0\%B4\%D0\%B8 Utolsó letöltés: 2017.11.28.

URL4: Tермальни джерела в України https://tsikaviy-svit.com/\%D1\%82\%D0\% B5\%D1\%80\%D0\%BC\%D0\%B0\%D0\%BB\%D1\%8C\%D0\%BD\%D1\%96-\%-

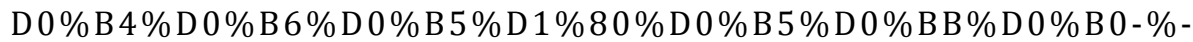
D0\%B2-\%D1\%83\%D0\%BA\%D1\%80\%D0\%B0\%D1\%97\%D0\%BD\%D1\%96 Letöltve: 2017.11.29.

URL5: Москаль: «Протягом 2017-го року на Закарпатти побувало близько 2 мильйонив туристив - це абсолютний рекорд!» http://www.carpathia.gov. ua/ua/publication/content/16405.htm Utolsó letöltés: 2018.01.04.

URL6: Керивни принципи туристичного бренду Закарпаття http://www. carpathia.gov.ua/data/upload/publication/main/ua/14649/brandbook_ zakarpattia.pdf Utolsó letöltés: 2018. 01. 05.

URL7: Welcome to Zakarpattia Официйний туристично-информацийний портал http://www.transcarpathiatour.com.ua/ Utolsó letöltés: 2018. 01. 05.

URL8: Мукачивський замок продовжує бити рекорди https://www.ukrinform. ua/rubric-tourism/2377274-mukacivskij-zamok-prodovzue-biti-rekordi.html Utolsó letöltés: 2018. 01. 06. 